\title{
PEDAGOJİK FORMASYON EĞİTIMİ ALAN ÖĞRETMEN ADAYLARININ OKUL, ÖĞRETMENLİK VE ÖĞRENCİ KAVRAMLARINA İLIŞKIN ALGILARI
}

\author{
Tuncay Yavuz ÖZDEMİ⿴囗1 \\ Yusuf Celal EROL 2
}

\begin{abstract}
ÖZ
Bu çalışmada pedagojik formasyon eğitimi alan öğretmen adaylarının okul, öğrenci ve öğretmenlik kavramlarıyla ilgili algıları metaforlar yardımıla belirlenmeye çalıșılmıștır. Bunun için öğretmen adaylarından bu kavramlar ile ilgili metaforları gerekçeleriyle birlikte üretmeleri istenmiştir. Katılımcı görüşlerinin içerik analizi yöntemi ile analizleri yapılmış ve görüşler yorumlanmıştır. 2013-2014 eğitim-öğretim yılı bahar döneminde Fırat Üniversitesi Eğitim Fakültesi'nde pedagojik formasyon eğitimine devam eden 216 öğretmen adayı çalışma grubu olarak belirlenmiştir. Okul kavramına ilişsin üretilen metaforlarda, okulun sistematik bir şekilde yaşama hazırladığı, bilgi ve kültür aktarılan bir yer olduğunu vurgulanmış ve öğrencilerin gizil güçlerinin okulda gün yüzüne çıkarıldığını söylenmiştir. Öğrenci kavramına ilişkin görüşlerde öğrencilerin öğretmenlerce şekillendirildiği, bilgiye aç ve işlenmeye hazır mücevher oldukları söylenmekte; ancak bu hazinelere de ilgi, şefkat ve sevgi anahtarlyla ulaşılabileceğini belirtilmektedir. Öğretmenlik kavramıla ilgili görüşlerde ise, öğretmenlik mesleğinin icra edilmesinde yaşanılan zorluklara, büyük sorumluluklar ve fedakârlıklar gerektirdiğine dikkat çekilmiştir. Çalışmada yer verilen görüşlere göre öğretmen adaylarının modern eğitim ve öğretim anlayışını yakalayamadıkları söylenebilir. Çünkü öğretmen adayları ögrretmeni şekillendiren, biçim veren, hayata hazırlayan, bilgi, aydınlık ve yaşam kaynağı olan bir kişi olarak nitelemektedir. Bu düşünceler öğretmen adaylarının geleneksel eğitim anlayıșına sahip olduklarını göstermektedir. Aynı $^{3}$ zamanda tutku ve değerli mücevher görüşlerinin de dile getirilmesi öğretmen adaylarının öğretmenlik mesleğinin kutsallığını içselleștirdiğini ve ögretmenlik mesleği motivasyonlarının yüksek seviyede olduğunu belirtmektedir. Çalışmada yer alan öğretmen adaylarının okul, öğrenci ve ögretmenlik kavramlarına ilişkin ürettikleri metaforlar ve yaptıkları açıklamalara göre yapılandırmacı yaklaşıma göre kendilerini hazırlamadıkları ve geleneksel öğretim yöntemlerini kullanmayı düşündükleri sonucuna ulaşılmiştır.
\end{abstract}

Anahtar Kelimeler: Metafor, Okul, Öğretmenlik, Öğrenci, Öğretmen adayl.

\footnotetext{
${ }^{1}$ Yrd. Doç. Dr., Fırat Üniversitesi, Eğitim Fakültesi, tyozdemir@gmail.com.

${ }^{2}$ Arş. Gör., Frrat Üniversitesi, Eğitim Fakültesi, yusufcelalerol@gmail.com.
} 


\title{
THE PERCEPTIONS OF PROSPECTIVE TEACHERS HAVING PEDAGOGIC FORMATION EDUCATION ABOUT THE NOTIONS OF SCHOOL, TEACHING AND STUDENT
}

\begin{abstract}
In this study, it is aimed to find out the perceptions of prospective teachers, who have pedagogic formation education, concerning the notions of school, student, and teaching with the help of metaphors. Therefore, the prospective teachers are asked to produce metaphors for each of these educational notions and then to explain their metaphors. The metaphors that are produced are evaluated using the content analysis method, and their explanations are categorized and commented on according to their similarities in determined themes. The study group consists of 216 prospective teachers who are the students of pedagogical formation program in the Education Faculty of Firat University in the spring term of 2013-2014 school year. In metaphors about the notion of school, it is stated that school is a place which systematically prepares students for life, and where culture and information are transferred, and that students' potential powers are brought to light in schools. In the views about the notion of student, it is highlighted that students are formed by teachers, that they are hungry for information and are like treasures and ores to be processed; but it is also indicated that these treasures are only reached with the key of interest, compassion, and love. In the views about the notion of teaching, the difficulties of teaching are pointed out. According to the participants, teaching requires big responsibilities and self-sacrifice. In accordance with the understanding of traditional education, teacher candidates believe that a teacher must be formative, a source of information, light, and life for the students, and prepare them to life. This belief shows that the modern understanding of teaching cannot be comprehended by the participants. At the same time, the participants' emphasis on the metaphors such as passion and treasure indicates that the prospective teachers internalize their profession as a divine task and that they have a high level of motivation for teaching. It is deduced from the views of the participants about the notions of school, student, and teaching that the prospective teachers do not prepare themselves with reference to the constructivist education theory and that they contemplate using traditional educational methods when they become teachers. Therefore, it is deduced that the content of the pedagogical formation programs must be restructured in accordance with modern educational understanding, and concentrate on practice, and accelerated applications must be abandoned.
\end{abstract}

Keywords: Metaphor, School, Student, Teaching, Teacher Candidate.

216 | Celal Bayar Üniversitesi Sosyal Bilimler Dergisi - Cilt: 13, Sayı: 4, Aralık 2015 


\section{Giriş}

Aynı ülkede yaşayan insanlara vatandaşlık bilinci kazandırmak ve o ülkenin ihtiyacı olan vasıflı insan gücünü yetiştirmeye çalışmak eğitim sistemlerinin en temel özelliğidir (Çelikten, Şanal ve Yeni, 2005). Ülkelerin gelişmişlik düzeylerini yükseltmeleri için vasıflı ve kendini geliştirmiş bir insan gücünün var olması ve bu vasıflı insan gücü kaynağının da etkili bir şekilde kullanılabiliyor olması gerekmektedir. Sosyal, ahlaki, ekonomik ve teknolojik yönden gelişmiş toplumlar, bu gelişmişliklerini kaliteli bir eğitim sistemlerinin olmasıyla sağlayabilmişlerdir. $\mathrm{Bu}$ nedenle toplumlar, eğitim ve öğretime büyük önem vermektedirler. Eğitime verilen önem, seviyesi farklı olsa da eğitimin vazgeçilmez bir olgu olduğu, her toplumun bir eğitim sisteminin olması ve bu sistemi geliştirmek için çabalamaları ile anlaşılmaktadır.

Toplumun her kesimine hizmet edecek bireyleri yetiștiren öğretmenler, ülkenin geleceğinin mimarı sayılabilirler (Çelikten, Şanal ve Yeni, 2005). Ülkelerin geleceklerinin şekillenmesinde öğretmenler çok önemli roller oynamaktadırlar. Öğretmenler, ülke kalkınmasında, insan kaynaklarının nitelikli olarak yetiștirilmesinde, toplumda huzur ve barış ortamının sağlanıp sürdürülmesinde, sosyalleşmiş ve toplumsal hayata hazır bireyleri hayata kazandırmada, toplumun kültür ve değerlerinin korunarak genç kuşaklara aktarılması ve aynı zamanda yeni yetișen nesil ile toplum arasında değişen şartlara göre uyum sağlanmasında başrol oynarlar (Özden, 1999). Yeni nesillerin niteliği de hiç kuşkusuz onu yetiştiren öğretmenlerin niteliği ile doğru orantılı olacaktır. Bu nedenle öğretmene, insan mimarı veya insanın kişiliğini biçimlendiren sanatkâr denilebilir (Çelikten, Şanal ve Yeni, 2005).

Benzer şekilde Şişman (2007), öğretmenin eğitim sisteminin en önemli öğesi olduğunu ifade etmektedir. Ancak bu denli önemli olan bu mesleği nitelikli, mesleğini seven, ileri düzeyde alan bilgisine, toplumun değer yargllarına, pedagojik eğitim ve genel kültür bilgisine sahip olan öğretmenlerin icra etmesiyle eğitim sisteminden yüksek düzeyde verim alabilmek mümkündür. Mesleğini sevmeyen, en son tercih olarak öğretmen olmayı tercih eden ve öğretmenliği sadece bir para kazanma işi olarak gören öğretmenlerin öğrencilere aktarabileceği davranışlar oldukça sınırlıdır. Toplumun öğretmenden beklentileri oldukça fazla olduğu için bu zorluklara göğüs gerebilmek ve bu beklentileri karşılayabilmek, öğretmenlik mesleğine gönülden bağlanmış ve idealleri olan öğretmenlerle mümkün olabilir.

Türkiye'de öğretmen yetiştirme konusu toplumdaki siyasal, sosyo-ekonomik ve kültürel gelişmelere bağlı bir yol izleyerek, öğretmenlerin mesleğe hazırlanması, birçok farklı uygulama ile gerçekleştirilmeye çalışılmıştır (Dündar ve Karaca, 2013). Bu 
uygulamalardan bazıları içerik ve uygulama şekli değişik olsa da hala devam etmektedir. Yedek subay öğretmenlik (1960- .....), vekil öğretmenlik (1961- ....), öğretmenlik formasyonu alarak öğretmen olarak atanma (1970-...), mektupla öğretmen yetiştirme (1974), hızlandırılmış programda öğretmen yetiştirme (1975-1980), tüm fakülte ve yüksekokul mezunlarının öğretmen olarak atanması (1996) (Akyüz, 2009, s. 390-391) uygulamaları öğretmen yetiştirme tarihimizde yer alan uygulamalardır.

Türk Milli Eğitim Sistemi'nde öğretmen yetiştirme konusunun öğretmenlik mesleğinin öneminin açık olmasına rağmen hala sistematik bir düzene oturtulamamış ve istikrarlı bir öğretmen yetiştirme politikası geliştirilememiştir. Eğitim fakülteleri mezunları dışından öğretmen alımı yapılmaktadır. Geçmişte mühendislik fakültesinden, veterinerlik fakültesinden pedagojik formasyona sahip olmayan bireyler öğretmen olarak atanmıştır. Günümüzde pedagojik formasyon belgesi öğretmen atamalarında aranan bir kriterdir. Öğretmen ihtiyacının pedagojik formasyon eğitimi almış öğretmen adaylarınca karşılanamaması halinde gerekli nitelikleri taşıyan öğretmen adaylarının atanmasının ardından, pedagojik formasyon eğitimi almamış, atama alanıyla ilgili bölümlerden mezun olan bireylerde adaylık süreci içerisinde pedagojik formasyon eğitimi verilmesi koşuluyla öğretmen olarak atanabilmektedir (Talim Terbiye Kurulu Başkanlığı, 2014).

1982 yllında Yüksek Öğretim Kurumu (YÖK)'nun kurulması ile öğretmen yetiştiren Eğitim Enstitüleri, Eğitim Fakültesi adı ile üniversitelere bağlanmış; öğretmen ihtiyacı, Fen-Edebiyat fakültesi mezunu öğrencilere pedagojik formasyon dersleri verilerek ve Eğitim Fakülteleri mezunlarını atayarak iki farklı kaynaktan giderilmeye çalışılmıştır (Yapıcı ve Yapıcı, 2013). Öğretmen yetiştirme konusunda YÖK, öğretmenlik sertifika programlarını, 04.11.1997 tarih ve 97, 39, 2761 sayılı kararlarıyla kaldırmıștır (YÖK, 1997). YÖK, ortaöğretim alan öğretmenliği için öğretmenlik sertifika programlarının uygulama, içerik ve süre konularında ihtiyacı karşılamadığını belirtip tezsiz yüksek lisans programları ile öğretmen yetiştirmeye başlamıștır (Yapıcı ve Yapıcı, 2013). Bu programlar Eğitim Fakültesi öğrencileri için 3,5+1,5 yıl, Fen-Edebiyat fakültesi mezunları için 4+1,5 yll olmak üzere iki şekilde yürütülmüştür (YÖK, 1997). Tezsiz yüksek lisans programlarının uygulanmaya konulmasıyla birlikte tüm öğretmenlik sertifika programları 1998-1999 öğretim yllında kapatılmıștır. Öğretmen yetiștirmede yapılan son değişiklik, YÖK genel kurulunun 2010 yılında aldığı karardır. Buna göre, tezsiz yüksek lisans programları kaldırılarak yerine tekrar pedagojik formasyon eğitimi getirilmiş ve eğitim fakültesi mezunu ya da öğrencisi olmayan bireyler, YÖK'ün izin verdiği üniversitelerin açtığ

218 | Celal Bayar Üniversitesi Sosyal Bilimler Dergisi - Cilt: 13, Sayı: 4, Aralık 2015 
Pedagojik Formasyon Kurslarına katılarak öğretmen olarak atanabilmektedirler (YÖK, 2010).

Türkiye'de eğitim sistemi ve öğretmen yetiştirme politikasındaki bu değişimlerin öğretmen adaylarının düşüncelerini nasıl etkilediğinin bilinmesi çok önemlidir. Özellikle de eğitim fakültesi dışındaki diğer fakültelerden mezun olan, pedagojik formasyon eğitimi alarak öğretmen olmuş veya olacak olan eğitim iş görenlerinin meslekleri ve meslekleriyle ilişkili konular hakkında ne düşündüğünün bilinmesi, pedagojik formasyon programlarının sağladığı verim hakkında öngörüde bulunmamıza yardımcı olabilir. Öğrencilerini olumlu ya da olumsuz etkileyecek olan öğretmen adaylarının eğitimin bileşenleri hakkındaki tutumu ve öğretmenlik mesleğini nasıl gördüklerin tespiti eğitim sistemimiz için hayati önem taşımaktadır (Kartal ve Afacan, 2013). Öğretmen adaylarının eğitim ve eğitimin bileşenleri hakkında ne düşündükleri yaptıkları metaforlar ve metaforlara yükledikleri anlamlar ile öğrenilebilir.

Metaforlar, bașka anlamda olan bir sözcüğün diğer bir sözcükle arasında bir ilişki kurularak, o kavramı ve kelimeyi daha anlaşılabilir ve daha zahmetsiz ifade etmek için kullanılırlar (Aydın, 2006). Miller (1987) da metaforu tecrübelerin dili olarak tanımlamaktadır. Bir metafor birden çok kelimeyle ifade edilemeyecek anlamı içinde barındırabilir. Kişinin öznel dünyasında düşündüklerini dışarıya daha rahat yansıtabilmesine firsat verir. Bir kavrama ilişskin kullanılan metafor insanın algılarının, tutumlarının ve bakış açısının anlaşılmasında oldukça yardımcı olur. Metafor kullanılırken soyut kavramların anlaşılmasında somut kavramlardan yardım alınmış olur (Çelikten, 2006). Böylelikle konu hakkında görüşlerine başvurulan katılımcıların düşünceleri derinlemesine incelenebilir ve katılımcllar kendilerini daha rahat ifade edebilirler. $\mathrm{Bu}$ çalışmada öğretmen adaylarının çeşitli eğitim kavramları hakkında kullandıkları metaforlar ve bu metaforlara yaptıkları açılamalar, kendilerini daha rahat ifade edebilmelerine ve somut kavramları kullanarak soyut kavramları açıklamalarına yardımcı olabilir ve araştırmacıların öğretmen adaylarının algı, tutum ve bakış açılarını detaylı bir şekilde incelemelerine olanak sağlayabilir.

Metaforlar iki benzeşmez olgu arasında bir ilişki kurulmasına veya belli bir zihinsel şemanın başka bir zihinsel şema üzerine yansitılmasına olanak vererek güçlü bir zihinsel model oluşturmaktadırlar (Saban, 2008: 460). Buna göre, herhangi bir metafor ilişkisinde, üç temel öğenin varlı̆̆ bulunur. (Forceville, 2002): (1) metaforun konusu (örneğin, "Öğretmenlik sarraflık gibidir." cümlesindeki "öğretmenlik" sözcüğü), (2) metaforun kaynağ (örneğin, "Öğretmenlik sarraflık gibidir." cümlesindeki "sarraflık" kavramı) ve (3) metaforun kaynağından metaforun konusuna 
atfedilmesi düşünülen özellikler (örneğin, "Öğretmenlik sarraflık gibidir; çünkü her öğrencinin içindeki cevheri görür, çıkarır ve işler. Öğrenciye baktığında herkes gibi bakmaz. 0 öğrencinin içindeki değeri ve yeteneği görebilir. Buna göre öğrenciyi değerlendirebilir."). Dolayısıyla, herhangi bir metafor ilişkisinde metaforun kaynağı, metaforun konusunu farklı bir bakış açısıyla anlamada ve açıklamada zihinsel bir "filtre" veya "süzgeç" işlevi görür.

Metaforların kullanımı, öğretmen adaylarının çeşitli eğitim kavramlarıyla ilgili tutumlarını ve algılamalarını belirlemede önemli bir araç olarak da kullanılabilir (Aydın ve Pehlivan, 2010). Metafor bir şeyi aradaki benzerliklerden yararlanıp başka bir şeyin yerine koyarak açıklamaya olanak sağlarlar (Saban, 2004). Sembolik ifadeler olan metaforlar, kelimelerin kendi anlamlarından başka anlamlara bürünüp, bireylerde başka anlamların oluşmasına sebebiyet verirler (Dündar ve Karaca, 2013). Lakoff ve Johnson (2005)'a göre metafor, bir anlamı başka bir anlam aracılı̆ğ ile anlamak ve ifade etmektir. Metaforlar yardımıyla bireylerin zihninde olup, ifade edilmeye çalışılan düşüncelerin daha az sözcükle ve daha vurgulu bir şekilde ifade edilmesine yardımcı olur (Akbaba-Altun ve Apaydın, 2013). Metaforlar doğayı ve çevresini anlamaya, anlamsız gibi görünen nesnel gerçeklikten belirli yorumlar yoluyla anlamlar çıkarmaya yardımcı olurlar (Yıldırım ve Şimşek, 2013). Bu araştırma ile pedagojik formasyon eğitimi alan öğretmen adaylarının okul, öğrenci ve öğretmenlik, kavramlarına ilişskin sahip oldukları algılarını metaforlar yardımıyla belirlemek amaçlanmıştır.

\section{Yöntem}

\subsection{Araştırmanın Deseni}

Çalışmada nitel araştırma desenlerinden olgubilim (phenomelogy) kullanılmıştır. Olgubilim yüzeysel olarak farkında olduğumuz olgulara daha derinlemesine ve ayrintılı olarak odaklanmaktır. Olgubilim araştırmaları kesin ve genellenebilir sonuçlar ortaya koymasa da bir olguyu daha iyi tanımamıza ve anlamamıza yardımcı olabilir (Yıldırım ve Şimșek, 2013).

\section{2. Çalışma Grubu}

Araştırmanın çalışma grubu, 2013-2014 eğitim-öğretim yılı bahar döneminde Fırat Üniversitesi Eğitim Fakültesi'nde pedagojik formasyon eğitimine devam eden 101 erkek ve 115 kadın olmak üzere toplam 216 lisans mezunu öğretmen adayından oluşmaktadır. Katılımcıların 44'ü Tarih, 28'i İlahiyat, 16'sı İngiliz Dili ve Edebiyatı, 12'si Müzik, 24'ü Matematik, 25'i Fizik, 23'ü Biyoloji, 11'i Kimya, 28'si Coğrafya, 5'i Türk Dili ve Edebiyatı bölümü mezunudur. Katılımcıların 144'ü daha önce özel bir kurumda ya da Milli Eğitim bünyesinde ücretli öğretmen olarak çalışmışlar ve öğretmenlik deneyimi edinmişlerdir.

220 | Celal Bayar Üniversitesi Sosyal Bilimler Dergisi - Cilt: 13, Sayı: 4, Aralık 2015 


\subsection{Veri Toplama Aracı ve Verilerin Toplanması}

Çalışma grubunda yer alan öğretmen adaylarının okul, öğretmenlik, öğrenci ve pedagojik formasyon kavramlarına ilişkin metaforlarını belirlemek için iki aşamalı bir form kullanılmıştır. Birinci aşamada, öğretmen adaylarından, okul, öğretmenlik, öğrenci ve pedagojik formasyon kavramlarını hangi metaforlarla ilişkilendirdiklerini belirlemek için "Okul ........... gibidir", "Öğrenci Gibidir", "Öğretmenlik ........... gibidir", İkinci aşamada ise öğretmen adaylarının öğretmenlik, okul ve öğrenci, kavramlarıyla ilişkilendirdikleri metaforları açılamaları amacıyla "Çünkü.............." kelimesi ile başlayan bölümü ayrıntılı olarak doldurmaları istenmiştir. Formun geliştirilmesi sürecinde eğitim bilimleri alanında uzman üç öğretim üyesinin görüşüne başvurulmuştur.

\subsection{Verilerin Analizi}

Araştırmada verilerin toplanması, analizi ve yorumlanmasında nitel araştırma yöntemlerinden tarama yöntemi kullanılmıştır. Nitel araştırma yaklaşımı doğrultusunda tasarlanan bu araştırmada "içerik analizi" yöntemi kullanılmıştır. Bu çalışma var olan durumu olduğu gibi belirlemeyi (Büyüköztürk, Kılıç Çakmak, Akgün, Karadeniz ve Demirel, 2014) amaçladığından betimsel nitelikte içerik analizi yapılmıştır. Wolcott (1994)'a göre betimsel analiz, toplanan verinin özgün biçimine olabildiğince bağlı kalınarak ve gerektiğinde araștırmaya katılan bireylerin ifadelerinden alıntılar yapılarak verilerin okuyucuya sunulmasıdır (akt. Yıldırım ve Şimşek, 2013: 252). İçerik analizinde ise amaç, verileri benzerliklerine göre belirli kavramlar ve temalar çerçevesinde bir araya getirilmesi ve bunları okuyucunun anlayabileceği bir biçimde düzenlenip yorumlanmasıdır (Yıldırım ve Şimșek, 2013: 259).

Öğretmen adaylarının ürettikleri metaforlar ve bu metaforlara ilişkin yaptıkları açıklamaların analiz edilmesi ve yorumlanması dört aşamada gerçekleştirilmiştir. $\mathrm{Bu}$ aşamalar şunlardır: (1) Verileri Bilgisayar Ortamına Aktarma Aşaması, (2) Tasnif Etme (Eleme ve Arıtma) Aşaması, (3) Kategori Geliştirme Aşaması, (4) Geçerlik ve Güvenirliği Sağlama Aşaması.

1. Verileri Bilgisayar Ortamına Aktarma Așaması: İlk olarak katılımcı görüşleri K1, K2, ... , K216 şeklinde kodlanarak bilgisayar ortamına aktarılmıștır.

2. Tasnif Etme (Eleme ve Arıtma) Aşaması: $\mathrm{Bu}$ aşamada "metafor analizi" teknikleri kullanılarak her metafor, parçalara ayrıştırıldı ve diğer metaforlarla olan benzerlikleri veya ortak özellikleri bakımından analiz edildi. $\mathrm{Bu}$ amaç için öğrencilerin yazdıkları metaforlar tekrar tek tek okunup gözden geçirilerek, her metafor (1) metaforun konusu, (2) metaforun kaynağı ve (3) 
metaforun konusu ile metaforun kaynağı arasındaki ilişki bakımından analiz edildi.

3. Kategori Geliştirme Așaması: Daha sonra her bir katılımcı görüşü incelenerek benzer görüşler gruplanmış ve temalar oluşturulmuştur. Her bir katılımcı görüşü anlamca yakın olan tema ya da temalara yerleştirilmiştir. Birden fazla temaya yerleștirilecek içerikte olan katılımcı görüşlerinin olması sebebiyle bazı görüşler birden fazla temaya da yerleştirilmiştir. Betimsel içerik analizi yaklaşımının benimsendiği bu çalışmada, araştırmanın kavramsal yapısı belirlenmiş, katılımcıların ilgili metafora iliş̧in düşüncelerinden doğrudan alıntılara yapılarak metaforlar desteklenmiştir. Yarı yapılandırılmış form ile elde edilen veriler sayısallaștırılarak frekans ve yüzde olarak ifade edilmiștir.

4. Geçerlik ve Güvenirliği Sağlama Aşaması: Nitel araştırmalarda en önemli problemlerden birisi de sonuçlarının inandırıcılığının sağlanmasıdır. Bu bağlamda geçerlik ve güvenirlik sağlanması çalışmaları bu inandırıcılığı sağlama konusunda en önemli ölçütlerin başında gelmektedir (Yıldırım ve Şimşek, 2013). Bu araştırma kapsamında da geçerliğin sağlanması amacıyla toplanan veriler ayrıntılı bir şekilde raporlanmaya çalışılmıştır. Ayrıca katılımcılardan alınan doğrudan alıntılara çalışma içerisinde yer vermek ve sonuçları bunlardan yola çlkarak yorumlamaya çalışmak da diğer bir geçerliği arttırma adımı olmuştur. Buna ilaveten bulguların yorumlanması ve değerlendirilmesi süreçlerinin detaylı bir şekilde açıklanması yardımıyla iç geçerlik ve dış geçerlik koşullarının da sağlanmasına çalışılmıştır (Miles ve Huberman, 1994).

Araştırmanın güvenirliğini sağlamak için oluşturulan metaforların belirttiğimiz kavramsal kategoriyi doğru bir şekilde temsil edip etmediğinin teyit edilmesi amacıyla uzman görüşüne başvurulmuştur. Araştırmada hakkında metafor oluşturulan kavramlar "okul, öğrenci, öğretmen" kavramlarıdır. Uzman görüşü sonrasında "Okul" kavramındaki 6 metaforun başka bir kategori içerisinde olduğu, diğer kategorilerin uyumlu olduğu belirtilmiştir. Örneğin "toplanma merkezi" metaforu araștırmacı tarafından "kaynaştırıcılık" kategorisinde yer aldığını belirtirken; uzman bunun yerine "birliğin simgesi" kategorisinin daha uygun olduğunu ifade etmiştir. Uzman görüşü ile araştırmacıların yaptığı kategorilerilendirmelerin karşılaştırılması sonucu görüş birliği ve görüş ayrılı̆̆ı sayıları tespit edilerek araştırmanın güvenirliği, Miles ve Huberman'ın (1994: 64) formülü (Güvenirlik = görüş birliği / görüş birliği + görüş ayrılığı) kullanılarak hesaplanmıştır. Nitel çalışmalarda, güvenirliği sağlamak için uzman ve araştırmacı değerlendirmeleri arasındaki uyumun $\% 90$ ve üzeri olması

222 | Celal Bayar Üniversitesi Sosyal Bilimler Dergisi - Cilt: 13, Sayı: 4, Aralık 2015 
beklenmektedir.(Saban, Koçbeker ve Saban, 2006; Saban, 2009). Okul kavramına ilişkin üretilen 188 farklı görüşten 6'sı uzman tarafından farklı kategoriye yerleştirilmiştir. Güvenirlik \% 96'dır. Öğrenci kavramına ilişkin üretilen 205 farklı görüşten 4'ü görüşüne başvurulan uzman tarafından farklı kategori için uygun görülmüștür ve güvenirliği \% 98 tespit edilmiştir. Öğretmenlik kavramına ilişkin öğretmen adaylarınca üretilen 213 görüșten ise 5 'i farklı bir kategoriye dâhil edilmiștir ve güvenirliği de $\% 97$ olarak bulunmuştur.

\section{Bulgular ve Yorum}

\subsection{Okul Kavramına İlişkin Bulgular}

Öncelikle araștırmacılar tarafından katılımcıların okul kavramına ilişkin algıları belirlenmeye çalışılmıştır. Katılımcılar okul kavramına ilişkin 188 farklı görüş bildirmiş ve bu görüşler araştırmacılar tarafından 7 farklı temaya yerleştirilmiştir. Katılımcı görüşlerinin tematik gösterimi șekil 1'de gösterilmiștir.

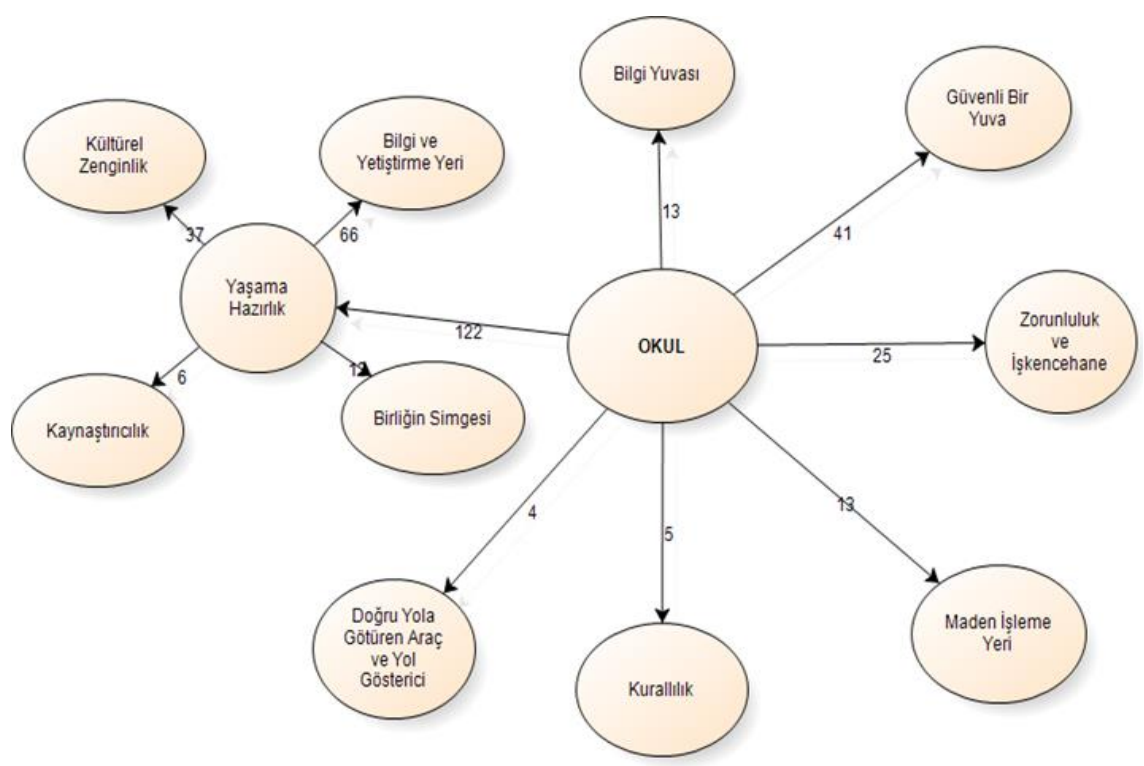

Şekil 1. Okul Kavramına İlişkin Metaforlar

Şekil 1'de görüldügü üzere katılımcıların okul hakkında ürettikleri metaforların yedi kategoriye ayrılmıștır. Bu kategoriler bilgi yuvası, güvenli bir yuva, zorunluluk ve işkence hane, maden işleme yeri, kurallılık, doğru yola götüren araç ve yol gösterici ve yaşama hazırlık olarak belirlenmiştir.

Okul hakkında ürettikleri metaforlar bilgi yuvası kategorisiyle ilişkilendirilen öğretmen adayları, cehaleti yok eden faydalı ve hayata dair öğrenilmesi gereken bilgilerin en verimli bir şekilde okul 
ortamında öğrenilebileceğini ifade etmektedirler. Okulun, öğrencilerin güven içerisinde kendilerini geliştirebilecekleri ve her gün yeni bilgilerin kazandırıldığı bir yer olduğuna vurgu yapılmıştır. Hayatı yönlendirmede atılacak adımların okulda öğrenilen faydalı bilgiler sayesinde doğru bir şekilde hatadan arındırılabileceği belirtilmiştir. Bu kategoriye ilişkin örnek katılımcı görüşleri şöyledir:

K102: "Okul bilgi yuvası gibidir; çünkü insan bilgiyi en güzel şekilde okulda ögrenir. Bilgi her birey, toplum ve ülke için bir kazanımdır. Yarın bu ülkeyi yönetecek insanlar bugün bu okullardaki ögrencilerdir. Ne kadar kaliteli ve bilgili insan yetişirse o derece kaliteli bir toplum olur."

K15: "Okul bilgi evi gibidir; çünkü öğrenciler hayatlarında ilk olarak burada öğretime başlar ve burada aldığı bilgilerle hayatına bir yön verir. Bu nedenle burayı öğrencinin bilgi aldığı ve hayatında önemli bir yer kaplayan gelecekteki yaşamını belirleyici öğesi olan bir bilgi evi olarak görüyorum."

Okulu doğru yola götüren araçla ilgilendiren pedagojik formasyon öğrencileri eğitim hayatının zorluklarla dolu olan bir süreç olsa da okulun yol göstericiliği sayesinde engellerin tek tek aşılabileceği ve gecede, karanlıkta, ıssız denizin ortasında deniz fenerlerinin gemilere yaptığı yönlendiricilik sayesinde gemilerin doğru yolu bulabilmesi gibi okulun da öğrencileri hata yapmaktan kurtarıp hayatın tehlikelerinin farkında olmalarını sağlayacağı katılımcılar tarafından ifade edilmiştir. Ayrıca okulun insanların önüne çlkan büyük bir firsat olduğundan ve varmamız gereken yere ulaştıracağından bahsedilmiştir. Genel anlamda bu şekilde özetlenebilecek katılımcı görüşleri doğru yola götüren araç ve yol gösterici temasına yerleştirilmiş ve dikkat çeken görüşlere aşağıda yer verilmiştir.

K150: "Okul gemi gibidir; çünkü onunla yol alırı. Gemide yolcu olması yolculuğun ilk şartıdır. Okullar da bizi doğru yola doğru götürmek için çıkmış bilgi gemileridir."

K196: "Okul deniz feneri gibidir; çünkü denizde ilerleyen gemiler fenere varamazlar ama fener olmadan da karanlikta yol bulamazlar. Dalgalı, karanlık zamanlarda ışığı ile yol gösterir. Deniz feneri olmazsa gemiler yol bulamaz."

Okul kavramını güvenli bir yuva kategorisinde değerlendiren katılımcılar okulda geçirilen zamanın uzunluğuna vurgu yaparak evde geçirilen zaman kadar okulda da vakit geçirildiğine değinmişlerdir. Okul ortamının bir yuva sıcaklığına, sevgisine, huzuruna ve rahatlığına sahip olduğu belirtilmekte, öğrencilerin okul sayesinde kendilerine değer verildiğinin bilincine sahip olmaya başladıkları ve okulda sadece bilgilerin öğrenilmediği ayrıca öğrencilerin burada hayata hazırlandığı ifade edilmektedir. 
Öğrencilerin okulda geçirilen bu uzun zaman içerisinde kendilerini okula ait hissetmeye başladıkları ve okul ile öğrencilerin arasında okuldaki paylaşımlar sonucu bir bağ oluştuğu ve gitgide okul ortamının geniş bir ailenin ortak yaşam alanına dönüştüğü görüşü katılımcılarımızın ortak fikirlerindendir. Bu yöndeki katılımcı görüşleri güvenli bir yuva temasına yerleștirilmiş ve önemli görülen katılımcı görüşleri aşağıda sunulmuştur.

K120: " Okul ev gibidir; çünkü öğrenci yeri geldiği zaman okulda aynı evindeymiş gibi rahat etmek aynı zamanda da huzurlu ve güvenli bir ortamda eğitimini tamamlamak ister. Öğretmenini aileden biriymiş gibi görmeye başladiğı zaman okulunu da evi gibi görmeye başlayacaktır."

K192: "Okul aile gibidir; çünkü öğrenci kendini ailesindeki gibi mutlu, değerli ve güvende hissetmelidir."

Kurallılık kategorisinde yer alan katılımcı görüşlerinde okuldaki disiplin faaliyetlerine verilen önem göze çarpmaktadır. Okuldaki yönetim iliş̧ileri göz önüne alınarak kurallara uyulması ve herkesin üzerine düşen görevi eksiksiz olarak yapması ön şartı ile okullarda eğitim-öğretim faaliyetlerinin hedeflenen nitelikte yapılabileceğine işaret edilmiştir. Okulun paydaşlarının kendi rollerine uygun bir şekilde okuldaki faaliyetlere katılması gerektiği aksi halde kurallara uymayanların okul ortamından dışlanacakları bu kategoride toplanan görüsslerin ortak özelliğidir. Așağıda kurallılık kategorisine yerleştirilen görüşlerden ikisine yer verilmiştir.

K203: "Okul disiplin yuvası gibidir; çünkü öğretme işi bașıboş yapılan bir iş değildir. Hem öğretmen hem de öğrenci belli kurallar ve disiplin çerçevesinde hayata hazırlamall, sosyalleşmelidir. Disiplinin olmadığı okul, harabe bir ev gibidir."

K103: "Okul kamp gibidir; çünkü belli kuralları ve aşamaları vardır. Bir kapta olduğumuzu varsayarsak, sürüden ayrılanı kurt kapar mantı̆̆ı işe girer. Okulla benzerliği ise kurallara uymayan dışlanır, yani okulda belli bir düzen işlemelidir."

Okul hakkındaki görüşleri maden işleme yeri kategorisi içerisinde yorumlanan pedagojik formasyon öğrencileri okuldaki faaliyetleri üretim ve işleme faaliyetlerine benzetip okula gelen öğrencilerin sistemin girdileri olduğunu ve okuldaki işleme ve üretim faaliyetlerinden sonra şekillendirilip çevreye çlktı olarak sunulduklarını söyleyerek, okuldaki faaliyetleri fabrika ortamında yapılan faaliyetlerle özdeşleştirilmiş ve toplumun aksayan yönlerinin bu fabrikalarda yapılan şekillendirme faaliyetlerinden sonra düzeltilebileceğini belirtmişlerdir. $\mathrm{Bu}$ kategoriye ilişkin örnek katılımcı görüşleri şöyledir:

K101: "Okul fabrika gibidir; çünkü öğretmenler öğrencileri işlemekte, onları şekillendirmektedir." 
K141: "Okul maden işleme yeri gibidir; çünkü öyle değerli madenler ancak sistemli bir şekilde işlenebilir. Bilmeyen ellerde yanlış işlenir, klymetsizleșir. Ancak okulda da çok dikkatli bir şekilde incelenip ona göre işlenmelidir. Yoksa okulun hiçbir anlamı kalmaz."

Diğer bir kategori olan zorunluluk ve işkence hane kategorisinde yer alan katılımcı görüşlerinin Türkiye'deki okul anlayışının köklü bir reforma ihtiyacı olduğu ve dolayısıyla toplumun beklentilerini karşılayamadığı dikkat çekmektedir. Okullardaki otorite boşluğu ve ciddiyetsiz yaklaşımlar yüzünden okulların amacından sapıp öğrencilerin okulun eğitim-öğretim amaçlarında yer alan kazanımların elde etmek için değil de zorunlu olduğu için okula geldikleri ve okula gelme görevlerini yapıp ve zamanlarını boşa geçirdikten sonra çıkış saatini bekledikleri göze çarpmaktadır. Bununla birlikte, okuldaki sert ve sıkıcı kurallara uyma zorunluluğu, bireysel farklılıkların dikkate alınmadan tek tip insan yetiştirme çabası, farklı fikirlere açık olmayışı ve öğrencilerin kendilerini rahat hissetmelerine firsat verilmeyişi eleştirilmektedir. Bu kategoride yer alan katılımcı görüşlerinden bazıları aşağıda yer almaktadır:

K133: "Okul işkence hane gibidir; çünkü öğrenciler öğretmenlerin otoritesizliği ve ciddiyetsizliğinden okulu eğitim yeri değil de sanki bu okula gelmek bir görev, geldik ve görevimiz bitti, saatimiz doldu, gidelim mantı̆̆ındalar."

K157: "Okul koşulsuz kabullenme yuvası gibidir; çünkü verilen her şeyin bireye kabullendirilmeye çalıșlldığı, disiplin adı altında bireyin robotlaştırıldığı ve koşulsuz kabullenmeye zorlandığı bir beton yığınıdır."

Farklı bir kategori olan yaşama hazırlık kategorisinde dört alt kategori oluşturulmuştur. Bunlar sırasıyla bilgi ve yetiştirme yeri, birliğin simgesi, kaynaştırıcılık ve kültürel zenginlik alt kategorileridir. Bilgi ve yetiştirme yeri alt kategorisinde katılımcılar bireyin bilgiyle eğitildiği, yetiştirildiği, davranışlarının şekillendirildiği, sosyalleștiği ve topluma kazandırıldığı yerin okul olduğunu, toplumun kültürünün okul aracılığıyla öğrenciye aktarıldığını, okulun bireylerin hayatlarındaki karanlık noktaları aydınlattığını ifade etmektedirler. Bilgi ve yetiștirme alt kategorine yerleştirilen görüşlerden dikkat çekici olanlara aşağıda yer verilmiștir:

K128: "Okul bahçe gibidir; çünkü o bahçeye her türlü bitki ekip yetiştirebilirsin ve o bitkiler birbirleri içerisinde uyumlu bir șekilde bir ormana dönüşür."

K39: "Okul harikalar diyarı gibidir; çünkü öğrenci burada doğruyu, yanlışı, eğitimi, hayatın sorunlarını öğrenerek sorunsuz, aydın, bilgili bireyler yetiştirilir. Ailesinden baskı gören bireyler okulda kendini rahat ifade etmeyi, kendi fikrini oluşturmayı ve hayatın 
zorluklarına karşı ayakta kalabilmeyi öğrenir. Okul eğitim yuvasl, sevgi-bilgi evidir. Insanın kendini rahat, huzurlu, mutlu hissettiği yerdir. Okul şah damarının çalışmasını sağlayan kalptir. Kalp çalışmazsa şah damarı görevini yerine getiremez. Okul da bunun için kusursuz çalışmalıdır, en iyi şekilde donatılmalıdır."

Birliğin simgesi alt kategorisinde okulun toplumun küçültülmüş hali olduğundan sosyal ihtiyaçları karşıladığı ve okulda öğrencilerin toplumlaşma yolunda büyük bir adım attığı ve binanın kolonlarının binayı ayakta tutması gibi okulun da toplumu ayakta tuttuğu bahsedilmektedir. $\mathrm{Bu}$ yöndeki katılımcı görüşlerinden bazıları şöyledir:

K34: "Okul binanın kolonları gibidir; çünkü okul olmazsa toplumun sosyalleșmesi zorlaşır. Okuldaki kaynașmalar toplumun kaynaşmasını sağlamaktadır. Okuldaki sosyalleşme, yardımlaşma ve dayanışma ne kadar güçlü olursa o kadar güçlü bir toplum meydana gelir."

K70: "Okul toplu yaşama ortamı gibidir; çünkü her çeşit insanın aynı ortamda kalıp birbirleri ile bir bütün olarak bir gün geçirirler. Toplumsal gelişim yeridir."

Kaynaştırıcılık alt kategorisinde formasyon öğrencileri, okulun belli bir amaç için birbirinden farklı olan bireyleri bir araya getirdiği ve toplumun ortak normları, değerleri ve inançları doğrultusunda harmanladığı belirtilmektedir. $\mathrm{Bu}$ alt kategoriye ilișkin örnek katılımcı görüșleri şöyledir:

K107: "Okul gökkuşağı gibidir; çünkü okulda birbirinden farklı birçok bireyin bir arada bulunduğu, değişik kültürlerin bir araya geldiği, buluştuğu renk cümbüşüdür."

K87: "Okul hayatların birleştiği bir çatı gibidir; çünkü her kesimden, duygudan, anlayıștan ve kültürden gelmiş bireyleri tek doğru, tek amaç doğrultusunda hayatı daha temiz kılmak için harmanlayan ögüten bir fabrikadır. Okullar toplumun sosyal yașamın bir aynası, bir sonucudur. Bu sebeple, okul fabrikasının içine attığımız çeşitli hammaddelerin daha kaliteli ürün vermesini sağlayacak güneş gibi okullara ve yıldız gibi öğretmenlere ihtiyaç vardır elbet."

$\mathrm{Bu}$ kategorinin son alt kategorisi olan kültürel zenginlik alt kategorisinde ise hayata dair öğrenilmesi gerekenlerin okulda öğrenildiği, öğrencilerin okulda etkileşim içerisine girerek olgunlaştığl, kültürlendiği ve hayata hazırlandı̆̆ı, bireylerin hayata bakış açılarının temellerinin okulda atıldığı ve okul ile yaşamın birbirinden ayrılmaz bir bütün olduğu vurgulanmaktadır. Aşağıda kültürel zenginlik alt kategorisine yerleștirilen görüsslerden iki görüşe yer verilmiștir:

K54: "Okul hayat gibidir; çünkü okulda öğrenilen bilgilerin büyük kısmı hayatta bize lazım olan bilgilerdir. Okul hayattan kopuk 
olmaz. Bireye hayatta öğrenmesi gereken bilgi ve becerileri kazandırır."

K114: "Okul yeni yaşam kapısı gibidir; çünkü okul her zaman kişsinin öğrendiklerini, yaşadıklarını, arkadaș, akran, büyük-küçük demeden herkesle etkileşimde olarak uyguladığı ortamdır. Yeni şeyler öğrenmek, yeni ilişsiler geliştirmek, birey olarak farkını görmek gibi birçok tecrübe alanını kapsar."

\section{2. Öğrenci Kavramına İlişkin Bulgular}

Öğretmen adaylarının öğrenci kavramına ilişkin algılarını irdelemek için kendilerinden alınan metaforları bilgiye aç bir varlık, bukalemun, çalışkan bir arı, geleceğin teminatı, hayatın anlamı, ilgi ve sevgi bekleyen varlık, işlenmemiş bir mücevher, şekillendirilebilen bir varlık, umutsuz bir varlık ve zenginlik olarak 10 kategori içerisine yerleştirilmiştir. Katılımcılar öğrenci kavramına ilişkin 205 farklı görüş bildirmişlerdir. Katılımcl görüşlerinin öğrenci kavramına ilişkin görüşlerinin tematik gösterimi şekil 2'de gösterilmiştir.

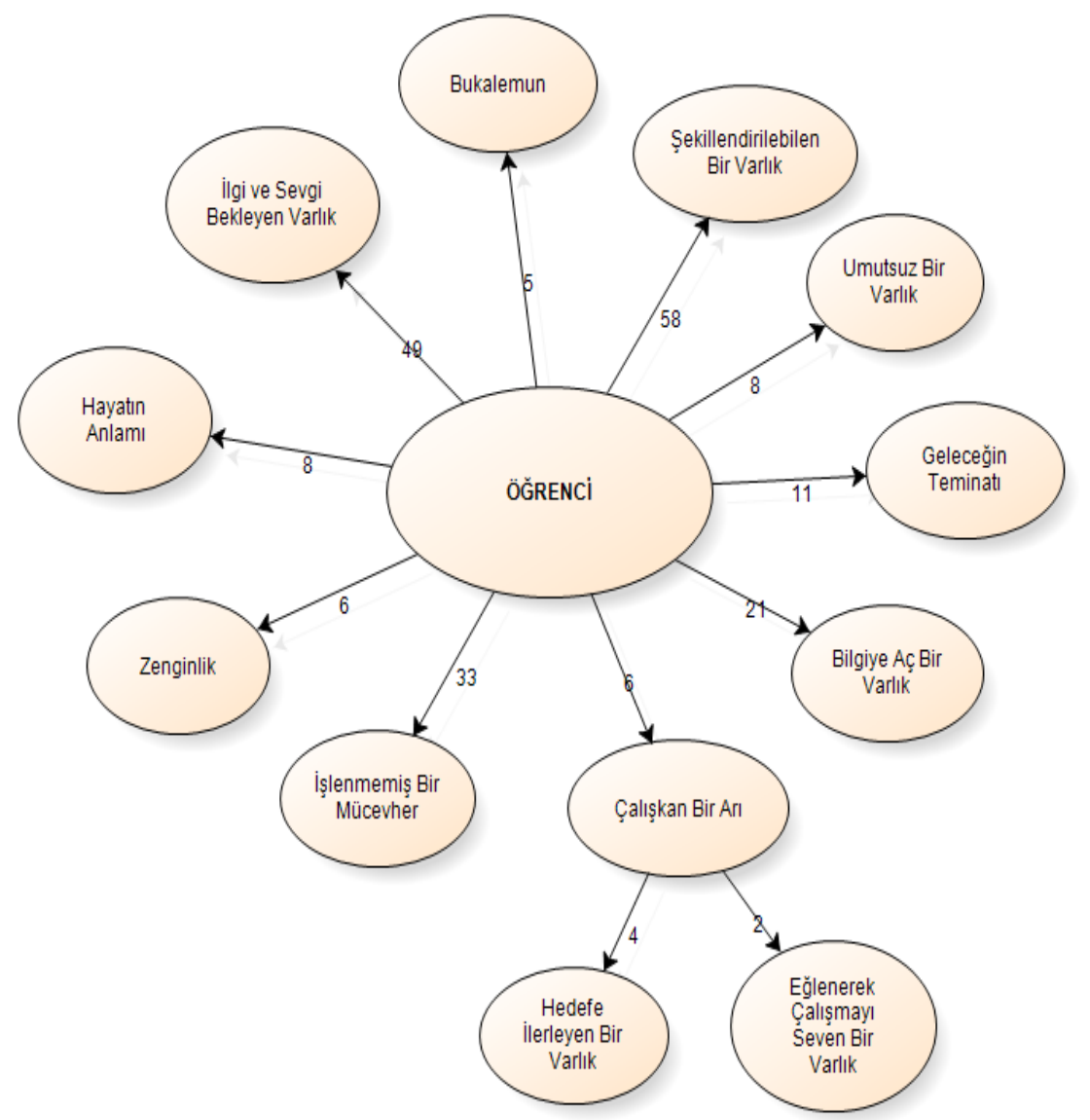

Şekil 2. Öğrenci Kavramına İlişskin Bulguların Tematik Gösterimi

228 | Celal Bayar Üniversitesi Sosyal Bilimler Dergisi - Cilt: 13, Sayı: 4, Aralık 2015 
Bilgiye aç bir varlık kategorisinde öğrencinin bilgiye olan ihtiyacı vurgulanmış, kendisini ve çevresini ilgilendiren konulara kayıtsız kalamadığı ve verilen bilgileri kayıt cihazı gibi hafızasına aldığı ve bu bilgileri ihtiyacı doğrultusunda kullanabildiği ve bu şekilde hayatın zorluklarına göğüs gerebildiği dile getirilmiştir. Ayrıca öğretmenlerin öğrenciyi yetiştirmede öğrencilerin bu özelliklerine karşı dikkatli olmaları gerektiği ifade edilmektedir. $\mathrm{Bu}$ kategoriye ilişkin örnek katılımcı görüşleri şöyledir:

K110: "Öğrenci aç bekleyen kişi gibidir; çünkü hemen hemen her şeyi öğrenmek ister. Özellikle kendisini ve çevresini ilgilendiren konuları ögrenmek ister."

K24: "Öğrenci hard disk gibidir; çünkü okulda ve okul dışında verilen bilgilerin çoğunu hafızaya alır ve yeri ve zamanı geldikçe bunları karşılaş̧ı̆̆ı problemlere uygulayıp yaşamın zorluklarının üstesinden gelir."

Bukalemun kategorisinde formasyon eğitimine devam eden öğretmen adayları öğrencileri not kaygılarından dolayı çıkarcı davrandıklarını, sınav odaklı olduklarını ve değişen şartlara ve çıkarlarına göre davranış kalıplarını değiștirebildiklerini belirtmektedirler. $\mathrm{Bu}$ kategoriye ilişkin örnek katılımcı görüşleri aşağıda yer almaktadır:

K147: "Öğrenci bukalemun gibidir; Çünkü sürüngenler sinıfinın familyasında bulunan bukalemun duygulara göre renk değiştirebilen bir türdür. Gözler bağımsız hareket eder. Çok yavaş yürürler fakat hedeflerine odaklanınca yemek istedikleri besini jet uçağından 5 kat daha hızlı bir șekilde kullandıkları dilleriyle avlarlar."

K154: "Öğrenci çıkarcı gibidir; çünkü bu dönemde öğrencili sadece sinavlara odakl olduğu için yüksek notla geçebilecekleri, sınavlara yönelik daha iyi soru çözen öğretmenlere yakınlık gösteriyorlar."

Çalışkan bir arı kategorisinde öğrencilerin durmadan ve bıkmadan hedefine ulaşıncaya kadar çalışmak ve başarmak zorunda oldukları vurgulanmıștır. $\mathrm{Bu}$ kategoriye ilişkin katılımcı görüşlerinden bazılarına aşağıda yer verilmiștir:

K10: “Öğrenci karın altındaki kardelen gibidir; çünkü hayatın hep güzel yönlerini bilir. Korkusuzca karın altından çıkmaya çalışır. Görmek, yaşamak ister. Öğretmen de onun karın altından çıkmasını, uzun süren hayatın zorluğunu, yararını, zararını öğrenmesini sağlar."

K26: "Öğrenci sporcu gibidir; çünkü hayatı boyunca bir koșuşturma içerisindedir. Durmadan, bıkmadan, usanmadan hedefe ulaşana kadar büyük bir azimle, sabırla koşusunu tamamlamaya çalışır. Bu hayat maratonu içerisinde bireyin hayatı ertelenmişliklerle dolu olur. Eğitim bir bakıma bireyi kısır döngü içerisine hapseder." 
Bilgiye aç bir varlık kategori eğlenerek çalışmayı seven varlık ve hedefe ilerleyen bir varlık iki alt kategoriden oluşmaktadır. Eğlenerek çalışmayı seven kategorisinde öğrencinin çalıştığı ortamı eğlenceli bir yere çevirme çabası ifade edilmiş; hedefe ilerleyen bir alt kategorisinde ise durmadan ilerlemesi ve karşısına çıkan her türlü zorluğa göğüs germesi gerektiği dile getirilmiştir. Bu şekilde özetlenebilecek katılımcı görüşlerinden dikkat çekici olan görüşlere aşağılda yer verilmiştir:

K207: "Öğrenci hayatı neşe ve eğlence ile yașamak gibidir; çünkü ögrrenci her an ve her yașta ortamı kendi eğleneceği, slkılmayacağı yer haline getirmeye çalışır. Canl, covıl cıvıl ve çok hareketlidirler."

K46: "Öğrenci yolcu gibidir; çünkü nasıl yolcu durmadan belli bir yoldan gitmesi gerekiyorsa ve gideceği yer belli ise oraya ulaşmak için durmadan ilerlemelidir."

Araştırmacılar tarafından belirlenen diğer bir kategori olan geleceğin teminatı kategorisinde, sağlıklı bir toplum oluşturmak için öğrencilere nitelikli bir eğitimin verilmesi gerektiği, öğrencilerimizin geleceğimizin teminatı olduğu ve gelişmiş devletler seviyesine iyi yetiştirilmiş nesiller sayesinde ulaşabileceğimizin altı çizilmektedir. $\mathrm{Bu}$ kategoriye ilişkin örnek katılımcı görüşlerinden dikkat çekici olan görüşler şöyledir:

K112: "Öğrenci gelecek toplumun aynası gibidir; çünkü bugün gelişen öğrenciye bakarak hem günümüzün hem de gelecek toplum yapısının analizini yapmak hiç de zor olmasa gerek. Öğrencideki alışkanlıkların nasıl bir aile ve toplumdan geldiğini ortaya koyar. Diğer boyutuyla gelișen ögrrencilerde merak ve ilgilerine dayanarak nasıl bir nesil geliştiğini de ortaya koyar."

K52: "Öğrenci gelecek gibidir; çünkü öğrenci bir devletin kalkınması demektir, güç demektir. Bir ülkenin öğrenci sayısı fazla olması ve bunların nitelikli bir şekilde yetişmesi ileride mensup olmuş olduğu devletinin kalkınmasını sağlar ve dünyaya önemli bilimsel bilgiler sağlayabilir."

Hayatın anlamı kategorisinde ise öğretmenlerin öğrencilerini kendi evlatlarından ayırmadığı, tüm haylazlıklarına rağmen öğretmenlerin öğrencilerinden kopamadığı söylenmektedir. Bu kategoriye ilişkin örnek katılımcı görüşleri şöyledir:

K65: "Öğrenci hayatı tanıma gibidir; çünkü farklı öğrencilerle karşılaşmaktayız. Bu öğrenciler bazen pozitif, bazen negatif yöne yönlendirebilir."

K45: "Öğrenci hayatı anlama gibidir; çünkü bir öğrenciyi anlamak aynı zamanda hayatı anlamak ve anlamlandırmaktır. Çünkü her insan bir hayattır." 
İlgi ve sevgi bekleyen varlık kategorisinde öğrencinin ihtiyaçları ön plandadır. Öğrencinin kendisine ve topluma faydalı bir birey haline gelebilmesi için öğretmenin sabırla, özveriyle, şefkat ve ilgi göstererek öğrencisini yetiştirme çabasının eğitimin sonuçlarının kısa bir zaman içerisinde ortaya çıkamayacağının ve uzun süre gerektirdiğinin de hesaba katılmasıyla karşıllksız kalmayacağı vurgulanmaktadır. Bu çabalar sonucunda aşllamaz görülen engellerin öğrenciler tarafından aşllabileceği ifadeleri dile getirilmektedir. Bu kategoride öğrencilerin anne-babanın evladı gibi öğretmenlere emanet olarak verildiği, hayatın zorluklarına karşı tecrübesiz ve savunmasız oldukları, ilgi, sevgi ve özveriye muhtaç oldukları, sahip oldukları gizil yeteneklerin gösterilen alaka sonucu ortaya çıkabileceği, yapılan yanlış bir davranışın öğrencileri olumsuz yönde etkileyeceği söylenmektedir. Bu şekilde özetlenebilecek katılımcı görüşlerinden dikkat çekici olan görüşlerden bazıları şöyledir:

K111: "Öğrenci bir bebek gibidir; çünkü bebek doğduğunda anne-babaya muhtaçtır. Öğrenci de öğretmenine muhtaçtır. Bundan sonra hayatında lazım olacak bilgileri kendisine aktaracak ve eğitecek birine ihtiyaç duymaktadır."

K139: “Öğrenci bambu ağacı gibidir; Çünkü bambu ă̆acı uzun yıllar bakılıp sulanmasına rağmen bir arpa boyu kadar büyümezler. Fakat bir gün birdenbire metrelerce uzunlukta bir ağaç haline gelirler. $B u$ uç bir örnek belki ama öğrencilerin her zaman neyi ne kadar özümsediğini göremeyebiliyoruz. Akademik anlamda da değerler anlamında da bu durum geçerlidir. Fakat kesinlikle her söylediğimizin, her öğrettiğimizin bir tohum olduğuna inaniyorum. Yeșerdiğini çoğu zaman göremiyoruz. Elbette ki tohumu içinde çürütenler de olacaktır. Yeşertenlerin çoğunlukta olduğu hüsnü zannını besliyorum. Velhasıl kelam verdiğimiz hiçbir çabayı küçümsemeden yolumuza devam etmeliyiz."

İșlenmemiş bir mücevher kategorisinde öğrencilerin her birisinde olan potansiyellerin öğretmenlerin onlara yardımları sonucu gün ışığına çıkabileceği ve kazandırılmak istenen bilgi ve becerilerin öğrencilere kazandırllabileceği belirtilmektedir. Öğrencilerin öğretmenlerinin giyim, kuşam, hal ve hareketlerini örnek almasıyla onların bir aynası olduğu vurgulanmakta, öğrencilerin öğretmenlerine göre kendi geleceklerini şekillendirdikleri ifade edilmekte, toplumun değer yargllarl, normları, inançları ve değerlerinin okulda öğrencilere kazandırıldığı dile getirilmektedir. İşlenmemiş mücevher kategorisine yerleştirilen görüşlerden önemli görülen görüşlere aşağıda yer verilmiştir:

K120: "Öğrenci henüz keşfedilmemiş değerli bir altın gibidir; çünkü ögrrenci küçük yaştan itibaren okula başlamış, henüz o saf ve 
temiz haliyle bütün bilgilere açık bir şekilde işlenmeye hazırdır. Bu görev de öğretmene düsser."

K35: "Öğrenci mücevher gibidir; çünkü onu işleyebilen, onu tanıyıp, onun seviyesine uygun eğitim verebilecek öğretmen elinde işlenip çok güzel bir kıvama getirilebilir. Ama işlenmemiş, ham haliyle hem bireyi kaybederiz, hem de topluma pasif bir birey katmış oluruz. Bireyi kazanmak ve onun bir değer olduğunu unutmamak çok önemlidir. Bir bireyi kaybetmek aslında toplumu yavaş yavaş kaybetmek demektir."

Şekillendirilebilen bir varlık kategorisinde öğrenciye kazandırılmak istenilen davranışların okul ortamında ve eğitim iş görenleri aracılığıyla kazandırılabileceği, öğrencinin okul, aile ve toplum nasıl yetiştirmek isterse o şekilde yetiștirilebileceği, eğer nitelikli bir eğitim verilmezse öğrencilerin topluma uyum sağlamada zorluklar yaşayacağı ve verilen eğitime kalitesinin yükseltilmesi gerektiği vurgulanmaktadır. Bu kategoriye ilişkin örnek katılımcı görüşleri şöyledir:

K115: "Öğrenci boş bir levha gibidir; çünkü neyle doldurmak isterseniz onu alır, zihninde depolar."

K127: "Öğrenci yoğrulmaya hazır bir hamur gibidir; çünkü eğitim ve ögrretime istekli bir birey her șey olmaya hazırdır. Önemli olan nitelikleri, özellikleri ve yetenekleri keşfederek öğrenciyi yönlendirme, hazırlama sürecinde ona destek olmaktır. Bu noktada elzem taraf yeni nesillerin öğretmenlerle gelişip gelişmeyeceğinin irdelenmesidir."

Umutsuz bir varlık kategorisinde ülkemizde verilen eğitimin nitelik yönünden eksiklikler içerdiği, öğrencinin ilgi ve ihtiyaçlarına yönelik bir eğitim yapılmadığı, öğrencilerin zorunlu olarak sürekli bir mücadele içerisinde yarıştırıldığı ve bu yarışın öğrencileri baskı altına aldığı ve bu durumun öğrencinin psikolojisini olumsuz yönde etkilediği söylenmiştir. Aşağıda umutsuz bir varlık kategorisinde yer alan görüşlerden iki görüşe yer verilmiştir:

K28: "Öğrenci mahkûm gibidir; çünkü sadece dinlemek ve emre boyun eğmekle yükümlüdür. Verileni ezberlemek ve ezberlediğiyle yașamak zorundadır."

K205: "Öğrenci köle gibidir; çünkü öğrenci 12 yıl zorunlu eğitim görmektedir. 12 yıl sonra ise okumak isterse lisede hayalini kurduğu yükseköğretim onun düşündüğ̈ gibi olmamaktadır. Özellikle yüksekögretim yıllarında hocaların zorlamaları, zorunlu kitap aldırmaları, ögrencilerin isteklerini almadan işlenen derslerin olması gibi nedenlerle ögrenciler bir köle gibi sürekli bir denetim ve zorlama altında kalmaktadır."

Zenginlik kategorisinde öğrenciler arasındaki bireysel farklılıkların zenginlik kaynağı olduğu ve bu zenginliklerin

232 | Celal Bayar Üniversitesi Sosyal Bilimler Dergisi - Cilt: 13, Sayı: 4, Aralık 2015 
keşfedilmeyi bekledikleri söylenmiş ve bu bireysel farklıklara ve çeşitliliğe dikkat edilerek eğitim-öğretim yapılması gerektiği belirtilmiştir. Bu kategoriye ilişkin örnek katılımcı görüşleri şöyledir:

K180: "Öğrenci kâinat gibidir; çünkü her ögrrenci farklı bir özelliğe sahiptir. Keşfedilmeyi bekleyen birçok özellikleri vardır. Bu da biraz ögrrencinin kendi çabası ve biraz da öğretmenin yardımıyla ortaya çıkabilir."

K181: "Öğrenci dünya gibidir; çünkü farklllıkları içinde barındırır. $O$ dünyanın içine girip anlayıp ona göre yönlendirilmesi, eğitim yöntemlerinin kullanılması gerekir."

\section{3. Öğretmenlik Kavramına İlișkin Bulgular}

Öğretmen adaylarını öğretmenlik kavramına ilişkin 213 görüş bildirmişlerdir. Öğretmen adaylarının düşüncelerini tutku, hayata hazırlama mesleği, ulașılması zor hedef, zor bir meslek, sorumluluk gerektiren bir meslek, fedakârlık mesleği, şekillendirici ve biçimlendirici bir meslek, değerli bir mücevher, yaşam kaynağı ve bilgi kaynağı olmak üzere 10 kategori içerisinde incelenmiş ve bu kategoriler şekil 3'te gösterilmiştir.

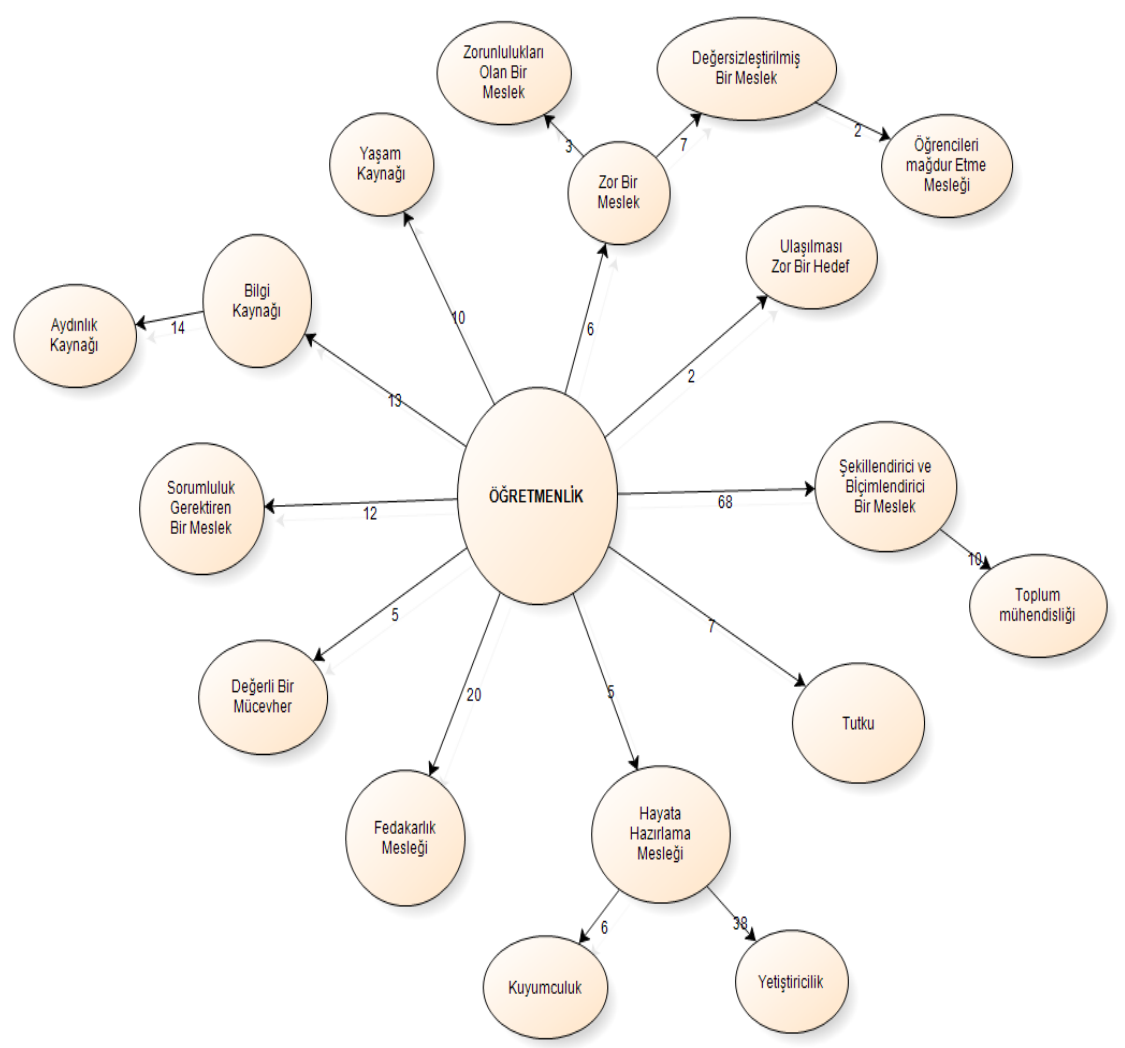

Şekil 3. Öğretmenlik Kavramına İlişkin Bulguların Tematik Gösterimi 
Tutku kategorisinde öğretmen adayları, öğretmenliğin insanları karşılık beklemeden sevmeyi gerektirdiğini, öğretmeye ve insanlara faydalı olmaya âşı bireyler tarafından bu mesleğin icra edilebileceği ve ancak idealleri olan insanların bu mesleği yapabileceğini vurgulamaktadırlar. Bu kategoriye ilişkin örnek katılımcı görüşleri şöyledir:

K178: "Öğretmenlik aşk gibidir; çünkü bağımlılık yapar. Aşk gibidir. Sevgidir, emektir, fedakârlıktır. Kendini unutup çocukları düşünmektir. Gözlerdeki pırıltıyı görüp mutlu olmaktır."

K204: "Öğretmenlik sevgi gibidir; çünkü sevgi olmadan, karşsllksız sevmeden ve karşıllksız bilgi vermeden yapılamaz. Sevmeden yapılan bir öğretmenlik yararlı bireyler ortaya çıkarmaz, aksine vatanını sevmeyen ve faydalı olmayan bireyler ortaya çıkarır."

Hayata hazırlama mesleği kategorisinde katılımcılar, öğretmeni özenli bir şekilde öğrencilerini yarınlara, hayata ve içinde yaşadığı topluma hazırlayan nitelikte bireyler olduğunu ifade etmişlerdir. Bu şekilde özetlenebilecek katılımcı görüşleri aşağıda yer verilmiştir:

K40: “Öğretmenlik anne-baba gibidir; çünkü birey ilk eğitimini (ahlaki değerler, kişilik yapısl, vb.) ailesinden alır ve öğretmen de anne babadan bireyin aldığı eğitimin üzerine katkılar sağlar. Okulda ihtiyaç duyduğunda ilk önce öğretmenine başvurur ve bu tutum doğrultusunda hayata bakışı gelişir. Öğretmen kimi zaman bireyin evde bulamadiğı eğitimi ve terbiyeyi verir."

K92: "Öğretmenlik bir çiçeği özenle yetiştirmek gibidir; çünkü nasil bir çiçeğe suyunu fazla verirsen veya hiç vermezsen kurur ve ölür. Öğretmenlikte de ögrrencilere bir şeyleri vermezsen, öğretmezsen veya onlardan fazlasını yapmasını isteyip aşırı yüklenme yaparsan ögrrenciler başarısız olur."

Hayata hazırlama mesleği kategorisinin kuyumculuk ve yetiştiricilik olmak üzere iki alt kategoriden oluşmaktadır. Kuyumculuk alt kategorisinde öğretmenin bir kuyumcu gibi öğrencileri yetenekleri, ilgi ve ihtiyaçlarına ve bireysel farklılıklarına göre özenle işlediği ve öğrencilerin içlerindeki yetenekleri gün yüzüne çıkarmalarında başat rol oynadığı dile getirilmektedir. Bu yöndeki görüşlerden dikkat çeken görüşler aşağıda sunulmuştur:

K141: "Öğretmenlik sarraflı gibidir; çünkü her öğrencinin içindeki cevheri görür, çıkarır ve işler. Öğrenciye baktığında herkes gibi bakmaz. O öğrencinin içindeki değeri ve yeteneği görebilir. Buna göre öğrenciyi değerlendirebilir."

K175: "Öğretmenlik kuyumculuk gibidir; çünkü kendinden katarak güzelleștirdiğin için kuyumcusun."

Yetiştiricilik alt kategorisinde öğretmenin öğrencilerin hayatta karşılaşabilecekleri olumlu veya olumsuz olaylara karşı

234 | Celal Bayar Üniversitesi Sosyal Bilimler Dergisi - Cilt: 13, Sayı: 4, Aralık 2015 
öğrencilerin deneyim kazanmasına yardım ettiği, öğrencilerini büyük dikkat, gayret ve titizlikle ve teorik bilgileri uygulamaya dökerek hayata hazırladığı, onların sorunlarıyla ilgilenerek onları çevrenin olumsuz etkilerinden koruduğu belirtilmiştir. Böylece öğretmenin öğrencilerin geleceğinin inşasında büyük pay sahibi olduğu söylenmekte ve öğrencilerin toplumun kültürüne uygun bir şekilde istenilen davranışları kazanmasında büyük pay sahibi olduğu ifade edilmektedir. Yetiştiricilik alt kategorinde yer alan katılımcı görüşlerinden örnekler aşağıdadır:

K104: "Öğretmenlik nadide bir bahçenin bahçıvanliğı gibidir; Çünkü çiçeğin yetişmesi için büyük gayret ve titizlik gerekir."

K128: "Öğretmenlik ă̆aç büyütmek gibidir; çünkü bir ağaç, fidandan başlayarak suyunu, gübresini, bakımını doğru yaparsan o ağaç bulunduğu çevre ve dünyaya fayda getirir."

Ulaşılması zor hedef kategorisinde formasyon öğrencileri öğretmen olmanın ve atanarak göreve başlayabilmenin çok zor olmasından şikayetçi olmuşlardır. Bu alt kategoriye ilişkin örnek katılımcı görüşlerinden önemli görülenlere aşağıda yer verilmiştir:

K58: "Öğretmenlik cennet gibidir; çünkü biz insanlar cenneti görmediğimiz halde anlatılanlardan ve de hayal edilmesinden bile çok mutluluk duyarız. Sanki cennetin o mis kokusunu koklamış gibi kendimizi huzur, sükûnet içinde hissediyoruz. İște benim için de öğretmenlik öyle. Şu an KPSS'ye hazırlanıyorum. Her ders çalıştığımda o atanmayı hayal ediyorum. Bu da beni çok mutlu ediyor."

K76: "Öğretmenlik hayal gibidir; çünkü KPSS'yi daha kazanamadım."

Zor meslek kategorisinde öğretmenlerin öğretmenlik mesleğinin insanların geleceğinin şekillendirildiği için yoğun çaba gerektiren bir meslek olmasına ve hatta bir yaşam tarzı haline getirilmesi gerekliliğine rağmen ülkemizde maddi ve manevi imkânsızlıklar içerisinde bulunmalarından dert yanılmaktadır. Bu kategoriye ilişkin örnek katılımcı görüşleri aşağıdadır:

K118: "Öğretmenlik zorluk gibidir; çünkü ülkemizin öğretmenlere göstermiş olduğu imkânları düşündüğümüzde hiç de mantıklı bir işmiş gibi durmuyor. Ama biz de çaresiz başka seçeneğimiz olmadığı için ögretmen olmak zorunda kalıyoruz."

K201: "Öğretmenlik yüklü kamyonla rampa çıkmak gibidir; çünkü öğretmenlik ağır bir meslektir. Rampada yüklü kamyon nasıl boğulursa öğretmenlik de bazen boğucudur. Külfetli bir yolda tabelasız ilerlemek, sis lambası olmadan yolunu bulmak gibidir."

Zor bir meslek kategorisinin alt kategorisi olan değersizleştirilmiş bir meslek alt kategorisinde, öğretmenlik mesleğinin kutsal bir meslek olmasına rağmen git gide değerini kaybettiği ve toplumdaki saygınlığını her geçen gün yitirdiği 
belirtilmektedir. Bu itibar kaybına nitelikli öğretmen eksikliği, öğretmenliğin garanti bir meslek olarak görülmesi, öğretmen olmanın giderek zorlaşması ve öğretmenlere sağlanan maddi imkânların yetersizliği sebep gösterilmekte ve bu itibar kaybı hem öğretmenlerin hem de öğrencilerin mağdur edilmesine neden olmaktadır. $\mathrm{Bu}$ alt kategoriye ilişkin örnek katılımcı görüşleri aşağıdadır:

K195: "Öğretmenlik az parayla çile çekmek gibidir; çünkü ögretmenliğin artı itibarı olduğunu düşünmüyorum. Niteliksiz insanlar aldıkları düşük maaşla fazla çaba göstermeden sırtını devlete dayamış hayatını garantilemiş bir halde karşısındaki çocuğun istikbalini önemsemiyorlar. Böyle olunca çocuk sadece bir çile olarak görünüyor göze."

K154: "Öğretmenlik soygunculuk gibidir; çünkü artık ögretmenler "Ne yaparım da bu çocuklar daha iyi bireyler olurlar, daha düşünceli, topluma daha yararl insanlar olurlar?" diyeceklerine "Ne yaparım da daha çok kazanırım, özel derslerim nasıl artar?" derdindeler. Okula daha az giderek daha çok kazanma derdindeler."

Zor bir meslek kategorisinin diğer bir alt kategori olan zorunlulukları olan bir meslek alt kategorisinde ise, öğretmenin önceden belirli olan bir müfredat çerçevesinde inisiyatif kullanamadan belirlenen kurallara göre davranması ve öğretim gerçekleştirmesi zorunluluğu ifade edilmiștir. Öğretmenler de bu kuralların dışına çıkamamakta ve kendi kararlarını kendileri alamamaktadırlar. Bu alt kategoriye ilişkin örnek katılımcı görüşleri aşağıdadır:

K14: “Öğretmenlik sözcü gibidir; çünkü eğitim ve öğretim, toplumların ekonomik, siyasi, kültürel şekillenişinde önemli etkenlerden biridir. Eğitim yoluyla küçük yaşlardan beri bireylerin hayata bakışı ve hayatı anlamlandırması hedeflenmektedir. Bu noktada belirlenen felsefi alt yapının benimsetilmesinde öğretmen de bir nevi aracı durumundadır."

K15: "Öğretmenlik emir eri gibidir; çünkü milli eğitimin kuralları ve programlarını belirlerken öğretmeni bir asker gibi kullaniyorlar. Söylenen sseylerin ve kuralların uygulanmasını ve emirlere uyulmasını sağllyorlar. Bu yüzden öğretmeni emirlerin dışına çıkamayan bir asker olarak görüyorum."

Sorumluluk gerektiren bir meslek kategorisinde öğretmen adayları öğretmenlere yüklenen vazifenin ağır bir sorumluluk gerektirdiğine ve öğretmenlerin onlara emanet edilen bireyleri tanıyıp ona uygun davranarak onların ve toplumun geleceğini şekillendirmek, bireyleri topluma kazandırmak, öğrencileri ahlaklı, bilgili, bilinçli, devletini ve milletini seven fertler olarak yetiştirmek

236 | Celal Bayar Üniversitesi Sosyal Bilimler Dergisi - Cilt: 13, Sayı: 4, Aralık 2015 
gibi sorumlulukları olduğuna değinmektedirler. Bu kategoriye ilişkin örnek katılımcı görüşleri şu şekildedir:

K91: "Öğretmenlik annelik gibidir; çünkü bir anne çocuğunun her șeyini bilip ona göre davranır. Ya da bir kelimeyle ne istediğini anlar, hangi sorunu olduğunu bilir. Öğretmen de öğrencilerini tanımalı ve ona göre davranmalıdır. Öğrencinin içinde bulunduğu duruma göre eğitim verir ona."

K35: "Öğretmenlik anne-baba olmak gibidir; çünkü eğitim ilk ailede başlar ve okul hayatında devam eder. Anne-baba sorumluluğunda bireyi yetiştirebilmek görev bilinciyle ve çocuğun bir değer olduğunu unutmadan ona hak ettiği eğitimi layıkıla verebilmektir ögrretmenlik. Vicdan işidir. Topluma bireyi kazandırabilmektir."

Fedakârlık mesleği kategorisinde öğretmenliğin öğrencilerin ruhsal, sosyal, bilişsel ve duyuşsal ihtiyaçlarını karşılayabilmek için gecelerini gündüzlerine katarak ve kendi yaşantısından feragat ederek sabır ve sebatla, dikkat ve özenle, hiçbir karşıllı beklemeden, özveriyle yapılabilecek bir meslek olduğu vurgulanmaktadır. $\mathrm{Bu}$ kategoriye ilișkin örnek katılımcı görüşleri şu şekildedir:

K116: “Öğretmenlik bir mum gibidir; çünkü kendisi tükenirken etrafını aydınlatır."

K38: "Öğretmenlik hamallık gibidir; çünkü hamal üzerine aldığı yükü dikkatli biçimde taşır, özen gösterir, zarar görmemesi için. Öğretmen de almış olduğu bu vazifeyi özenle taşımalı, ince ayrıntılarına kadar bildiği objeleri ögrretmelidir. Sanki sirtında yumurta küfesi taşıyormus gibi hissetmeli ögretmen. Hassasiyetini bu şekilde göstererek hem kendini kanıtlamalı hem de çevresini olumlu şekilde etkilemelidir."

Şekillendirici ve biçimlendirici kategorisinde öğretmenlik mesleğinin sürekli olarak öğrencileriyle ilgilenerek, bilgi, beceri ve önderlik kabiliyetleriyle birbirinden farklı özelliklere sahip öğrencileri uyum içerisinde öğrenme faaliyetleri içerisine katmasını gerektirdiği ifade edilmiştir. Öğretmenlerin öğrencilere rol model olarak, öz güven aşllayarak ve yol göstererek rehberlik eden ve yönlendiren, öğrencilerin kendi seçimlerini yapmalarında onlara kllavuzluk ederek onların en doğru tercihleri yapmalarında önemli pay sahibi olan kișiler olduğu dile getirilmektedir. Bu kategoriye ilişkin örnek katılımcı görüşleri şu şekildedir:

K146: “Öğretmenlik yönetmenlik gibidir; çünkü öğretmen öğretilecek bilgiyi, öğrencinin kazanması gereken davranışları kurgulayan ve bu anlamda öğrenciye rehberlik edip yol gösteren kişidir."

K167: "Öğretmenlik heykeltıraşlık gibidir; çünkü bir bireyi yönlendirmek, ona ilgi ve beklentileri doğrultusunda şekil verme işidir. 
Yalnız bu işi yaparken öğrencinin ilgi ve beklentileri yok sayılmamalıdır. Öğretmenler kendini sınıfin mutlak hâkimi olarak değil de öğrencilerine yol gösterici bir kılavuz niteliğinde olmalıdır."

$\mathrm{Bu}$ kategorinin alt kategorisi olan toplum mühendisliği alt kategorisinde ise bilgili, sağlıklı ve nitelikli bir toplumun temelini öğretmenlerin attığı söylenmektedir. Bu alt kategoriye ilişkin örnek katılımcı görüşleri şu şekildedir:

K158: “Öğretmenlik yönetmenlik gibidir; çünkü bir film için neler gerektiği, nasıl olması gerektiği yönetmenin elindedir. Öğretmen ve öğrenci açısında düşünürsek herkese belli roller verilmiş, ögrretmen de bunun şekillenmesinde yardımcl olan ve yönlendiren yönetmendir."

K198: "Öğretmenlik güneş gibidir; çünkü topluma gelecek için sağlam temelleri oluşturan toplum mühendisliğinin ana merkezidir. $\mathrm{Bu}$ ana merkez doğrultusunda güneş gibi olan öğretmen toplumu aydınlatır ve gelecek için umutlu bir ortam sağlar. Bu toplum önce kendi yerel alanına daha sonra bölgesine ve ülkesine etki etmektedir. Toplumun geleceği için de öğretmenin güneş gibi olması şarttır."

Değerli mücevher kategorisinde öğretmenlik mesleğinin toplumun ve toplumu oluşturan bireylerin geleceklerinin şekillenmesinde oynadı̆̆ı rol göz önüne alınarak paha biçilemeyecek bir klymette değerli bir meslek olduğu belirtilmektedir. $\mathrm{Bu}$ kategoriye ilișkin örnek katılımcı görüșleri şu șekildedir:

K1: "Öğretmenlik pırlantadan yapılmış kristal vazo gibidir; çünkü öğretmenliğin çok değerli ve paha biçilmez bir değeri vardır."

K7: "Öğretmenlik mücevher satan esnaf gibidir; çünkü isteyen alır, gerçekten algılayan faydalanır ve bakan değil gören faydalanır."

Yaşam kaynağl kategorisinde de öğretmenlerin ailesinin okula emanet ederek yolladığı öğrencileri hayatta lazım olan bilgi ve becerilerle donatarak hayata hazırladığı, hayatın zorluklarına karşı koruduğu ve böylelikle öğrencilerin toplumun faydalı birer parçası olmasında büyük pay sahibi olduğu formasyon öğrencilerinin ortak görüşü olarak özetlenebilir. Bu kategoriye ilişkin örnek katılımcı görüşleri şöyledir:

K10: "Öğretmenlik ă̆acın kökü gibidir; çünkü öğretmen olmazsa öğrenci kavramı olmaz. Öğretmen ağacın kökü gibi mineralleri, suyu çeker ve ağaca aktarır."

K95: "Öğretmenlik nefes gibidir; çünkü öğretmenler ögrrencilere nefes alıp vermeyi yani yaşamayı öğretirler."

Bilgi kaynağı kategorisinde ise öğretmenin bilgiye aç olan öğrenciye bilgi aktaran ve öğreten yönü vurgulanmıștır. Öğretmenin sürekli olarak kendini geliștirmesi gerektirdiği ve öğrencilerin bilgi ihtiyaçlarına karşılık verebilecek bir kapasitede olması gerektiği söylenmektedir. Sahip olduğu bilgilerle eğitim ve öğretime ihtiyacı olan öğrencileri ve toplumu cahillik karanlığından kurtardığı ve

238 | Celal Bayar Üniversitesi Sosyal Bilimler Dergisi - Cilt: 13, Sayı: 4, Aralık 2015 
onlara yeni bakış açıları kazandırdığı belirtilmektedir. Bu kategoriye ilişkin örnek katılımcı görüşleri şöyledir:

K20: “Öğretmenlik ansiklopedi gibidir; çünkü her türlü öğrenci ögretmene her konudan soru sorabilir. Öğretmen de her türlü soruya açık olmalı ve her türlü soruya cevap verebilecek kapasitede olmalıdır. Sorulan her kavramın tanımını yapabilmeli ve öğrenciye yetebilmelidir."

K24: "Öğretmenlik bilgisayar gibidir; çünkü sürekli bilgileri güncellemek ve yenilemek zorundadır. Geniş bir bilgi birikimine sahip olması şarttır. Öğrencinin yaşamla ve diğer alanlarla ilgili öğrenciye doğru yolu gösteren bir rehberdir. Bilgileriyle öğrenciyi aydınlatır."

\section{Tartışma, Sonuç ve Öneriler}

$\mathrm{Bu}$ çalışmada, pedagojik formasyon eğitimi alan 216 öğretmen adayının, eğitim kavramlarından olan okul, öğrenci ve öğretmenlik kavramlarıyla ilgili benzetmeler yapmaları ve yaptıkları bu benzetmeleri açıklamaları istenmiştir. Bu şekilde eğitim fakültesi mezunu olmayan öğretmen adaylarının, ürettikleri metaforlar yardımıyla değinilen eğitim kavramlarına ilişkin algılarının ortaya çıkarılması amaçlanmıştır.

Katılımcılar okul kavramına ilişkin ürettikleri metaforlarda, geleneksel eğitim anlayışına uygun olarak, okulun sistematik bir şekilde yaşama hazırladığını ve bilgi ve kültür aktarılan bir yer olduğunu vurgulamışlar ve öğrencilerin gizil güçlerinin okulda gün yüzüne çıkarıldığını söylemişlerdir (163 görüş). Ancak görüşlerin bir kısmı da eğitim sistemindeki sıkıntılara dikkat çekerek okulların beklentilere cevap veremediğini ve modern çağda okulda zorunlu eğitim görmenin yanlıș olduğunu belirterek, eğitim sisteminin köklü reformlara ihtiyacı olduğunu ifade etmiş̧lerdir ( 25 görüş̧). Nalçacı ve Bektaş (2012)'ın çalışmalarında, öğretmen adaylarının çoğunluğu okul kavramını güven verici ve bilgi sağlayıcı olarak tanımladığına dikkat çekmişler ve katılımcıların okul kavramına ilişkin olumlu bir imaja sahip olduğunu vurgulamışlardır. Fakat aynı çalışmada (Nalçacı ve Bektaş, 2012), öğretmen adaylarının bir kısmının okulu fabrika ve hapishaneye benzetmeleri, mesleklerini icra edecekleri yer hakkında olumsuz imajlarının bulunduğunu, öğretmen adaylarının meslek güdülerinin yeterli olmadığını ve algılardaki okul imajlarını olumlu yöne kanalize etmek için radikal değişiklere ihtiyaç olduğunu söylemeleri, bu çalışmadaki bulguları destekler niteliktedir.

Pedagojik formasyon öğrencilerinin öğrenci kavramına ilişkin algılarını belirlemek için kendilerinden alınan metaforlar ve açılklamaları doğrultusunda oluşturulan kategorilere göre öğrenciler hakkında görüşlerinin çok büyük bir kısmının olumlu olduğu görülmektedir (192 görüş). Öğrencilerin her birinin eşsiz kıymette hazineler olduğu; ancak bu hazinelere de ilgi, şefkat ve sevgi 
anahtarıyla ulaşılabileceği belirtilmektedir. Ayrıca öğrencilerin öğretmenlerce şekillendirildiği (58 görüş), bilgiye aç oldukları (21 görüş) ve işlenmeye hazır mücevher (33 görüş) oldukları dile getirilmiştir. Türkçe öğretmeni adaylarının öğretmen ve öğrenci kavramlarına ilişkin kullandıkları metaforlara dayalı algılarının tespit edildiği Aydın ve Pehlivan (2010) tarafından yapılan çalışmada, Türkçe öğretmeni adaylarının çoğunlukla öğretmeni bilgi kaynağı, üretici ve biçimlendirici olarak, öğrenciyi ise bilgi alıcısı, üretilen ve biçimlendirilen olarak gördükleri belirlenmiştir. Aydın ve Pehlivan (2010)'ın ulaştıkları bulgular ile bu araștırmada belirtilen bulgular benzeşim göstermektedir. Olumsuz görüşler arasında bukalemun (5 görüş) ve umutsuz bir varlık (8 görüş) kategorilerinde öğrencilerin not kaygllarının öğrencileri farklı davranışlara yönelttiği, verilen eğitimin niteliksel olarak yetersiz kaldığı ve sınav odaklı olan eğitim sisteminin öğrencide istenilen olumlu davranış değişikliğini sağlayamayacağı ifade edilmiştir.

Öğretmen adayları öğretmenlik kavramıyla ilgili görüşlerinde, öğretmenlik mesleğinin icra edilmesinde yaşanılan zorluklara, büyük sorumluluklar ve fedakârlıklar gerektirdiğine dikkat çekmişlerdir (38 görüş). Bununla birlikte, öğretmen olarak atanmanın zorluklarına (2 görüş) ve öğretmenlik mesleğinin toplum nezdinde değersizleştirildiğine (7 görüş) de değinmişlerdir. Öğretmenlik mesleğinin değersizleştirildiğinin düşünülmesi öğretmen adaylarının meslek motivasyonlarını olumsuz etkileyebilir ve iş doyumlarını düşürebilir. Geleneksel eğitim anlayışında yerini bulan şekillendirici ve biçimlendirici (78 görüş), bilgi ve aydınlık (27 görüş) ve yaşam kaynağı olan öğretmen (10 görüş), hayata hazırlama mesleği (5 görüş) ve yetiştiricilik (38 görüş) anlayışları da öğretmen adaylarının modern eğitim ve öğretim anlayışını yakalayamadıklarını gösterebilir. Aynı zamanda bu görüşler ve tutku (7 görüş) ve değerli mücevher (5 görüş) görüşleri öğretmen adaylarının öğretmenlik mesleğinin kutsallığını içselleştirdiğini ve bu görüşlerin sahiplerinin öğretmenlik mesleği motivasyonlarının yüksek seviyede olduğunu belirtebilir.

Saban (2004) 151 giriș düzeyindeki sınıf öğretmeni adayının "öğretmen” kavramına ilişkin metaforlarını incelediği araştırmasında, öğretmen adayı öğrencilerin yaklaşık üçte ikilik kısmının (\%64) öğretmeni "bilginin kaynağı ve aktarıcısı", "öğrencileri şekillendirici ve biçimlendirici" ve "öğrencileri tedavi edici" olarak algıladığını, geriye kalan üçte birlik kısmının da (\%36) öğretmenlerin "öğretirken eğlendirmesi", "öğrencilerin bireysel gelişimlerini desteklemesi" ve "öğrencilere öğrenme surecinde rehberlik etmesi" metaforlarını kullandığını tespit etmektedir. Giriş düzeyindeki öğretmen adayları ile formasyon eğitimi alan öğretmen 
adaylarının büyük kısmının öğretmeni bilgi sağlayıcısı ve aktarıcısı olarak görmesi ve öğretmenin rehberlik ederek öğrencinin kendi bilgilerini yapılandırmasına yol göstermesi gerektiğini ifade etmemesi formasyon eğitiminin öğretmen adaylarının görüşlerinde değiş̧iklikler yapmaya yeterli olmadığını gösterebilir. Akbaba Altun ve Apaydın (2013), kız ve erkek öğretmen adaylarının eğitim kavramına ilişkin metaforik algılarının belirlenmesine yönelik araştırmalarında, öğretmen adayı öğrenciler eğitimi kaliteli yasam sağlamada etkili, bilgi sağlayıcı ve şekillendirici olarak görmektedir. Her iki araştırmanın bulgularına göre öğretmen adayı öğrencilerin gerek öğretmeni gerekse eğitimi bilgi sağlayıcı ve şekillendirici olarak yorumladıkları görülmektedir. Yılmaz, Göçen ve Yılmaz (2013), Öğretmen Adaylarının Öğretmen Kavramına İlişkin Algıları" isimli çalışmalarında da öğretmen adaylarının, öğretmen kavramını anne-baba, aile, bahçıvan, rehber, ışık, çoban gibi metaforlarla açıkladıkları ve en çok tekrar eden metaforun "anne-baba, aile, bahçıvan" metaforları olduğu görülmüş, öğretmen adaylarının hayatlarında kendi öğretmenlerinin önemli bir yer tuttuğu, öğretmenleriyle fazla zaman geçirdikleri ve öğretmenlerini rol model olarak almalarından kaynaklandığı sonucuna ulaşılmıştır. Ayrıca çalışmalarında çıkan diğer önemli sonuç öğretmen adaylarının mesleklerine ilişkin statü kaygısı taşıdıklarını tespit etmeleridir. Yılmaz, Göçen ve Yılmaz (2013)'ın çalışmaları ile bu çalışmanın sonuçlarının benzerlik göstermesi eğitim fakültesi öğrencileri ile formasyon öğrencilerinin benzer şekilde düşündüklerini göstermektedir. Kartal ve Afacan (2013) ise pedagojik formasyon eğitimi alan öğretmen adaylarının öğretmenlik mesleğine yönelik genel tutumlarının orta düzeyin üzerinde olduğu ve $\% 60$ oranında öğretmenlik mesleğine yönelik kendilerini yeterli gördüklerini saptamışlardır.

Geleneksel eğitim sistemlerinde eğitime bir tedavi etme aracı veya bir üretim aracı olarak bakılmaktadır. Bu anlayışa göre eğer eğitim bir üretim aracı ise okullar birer fabrika, öğretmenler birer teknisyen ya da imalatçı, öğrenciler ise hammadde olacaktır. Eğitime tedavi etme aracı metaforu ile bakacak olursak da okullar hastane, öğretmenler doktor, öğrenciler ise birer hasta olmaktadırlar. Her iki metaforda da vurgulanan öğrenciler pasiftirler. Bu anlayışlar modern eğitim anlayışları ile uyuşmamaktadır (Cook-Sather, 2003).

$\mathrm{Bu}$ anlayışı doğrular şekilde bu çalışmada da yer alan katılımcıların okul, öğrenci ve öğretmenlik kavramlarına ilişkin görüşlerinden yola çıkılarak öğrencilerin edilgen ve sessiz olmadığı, etkinliklere aktif katılım gösterdiği, öğretmenin anlatıp öğrencinin dinlediği geleneksel eğitim anlayışının olmadığı ve öğretmenin öğrenenleri yönlendirdiği yapılandırmacı yaklaşıma (Erdem ve 
Demirel, 2002) göre kendilerini hazırlamadıkları ve geleneksel öğretim yöntemlerini kullanacaklarını sandıkları sonucuna ulaşılabilir. Saban (2008) öğretmen yetiştirme programındaki derslerin yapılandırmacı eğitim yaklaşımı anlayışıyla yapılandırılmadığını söylemektedir. Bu durum, formasyon eğitimi alan öğretmen adaylarının görüşleri ile doğrulanmaktadır. Ayrıca, pedagojik formasyon öğrencilerinin gelecekteki meslekleriyle ilgili olan okul, öğrenci ve öğretmenlik kavramlarına ilişkin algılarının genellikle olumlu olduğu çalışmanın başka bir bulgusudur.

$\mathrm{Bu}$ çalışma Fırat Üniversitesi Pedagojik Formasyon Birimi 2013-2014 eğitim-öğretim yllı pedagojik formasyon öğrencilerinin görüşleri ile sınırlıdır. Benzer çalışmalar diğer üniversitelerde eğitim görmekte olan pedagojik formasyon öğrencileri ile yapılabilir. Ayrıca eğitim fakültesinde eğitim görmekte olan öğretmen adaylarının da çeşitli eğitim kavramlarına ilişkin algıları tespit edilerek formasyon öğrencilerinin algılarıyla karşıllaştırmalar yapılabilir. Formasyon eğitimi alan öğretmen adaylarının öğretmen olduktan sonra aynı eğitim kavramlarına ilişkin algılarının tespit edilmesi ve daha önce belirlenen algılarıyla farklılaşmalar olup olmadığının tespiti yapılabilir.

\section{KAYNAKLAR}

AKBABA-ALTUN, S. ve APAYDIN, Ç. (2013). Kız ve Erkek Öğretmen Adaylarının Eğitim Kavramına İliş̧kin Metaforik Algıları, Kuram ve Uygulamada Eğitim Yönetimi Dergisi, 19(3), ss. 329-354.

AKYÜZ, Y. (2009). Türk Eğitim Tarihi, Gözden Geçirilmiş 15. Baskl, Ankara: Pegem Akademi Yayınları.

AYDIN, İ., H. (2006). Bir Felsefi Metafor "Yolda Olmak", Din Bilimleri Akademik Araştırma Dergisi, 4(3), ss. 9-22.

AYDIN, İ., S. ve PEHLIVAN, A. (2010). Türkçe Öğretmeni Adaylarının "Öğretmen" ve "Öğrenci" Kavramlarına İlişkin Kullandıkları Metaforlar, Turkish Studies, 5(3), ss. 818-842.

BÜYÜKÖZTÜRK, Ş., KILIÇ ÇAKMAK, E., AKGÜN, Ö., E., KARADENIZ, Ş. ve DEMİREL, F. (2014). Bilimsel Araştırma Yöntemleri, Ankara: Pegem Akademi Yayınları

COOK-SATHER, A. (2003). Movements of mind: The Matrix, metaphors, and re-imagining education, Teachers College Record, 105, ss. 946-977.

ÇELIKTEN, M. (2006). Kültür ve Öğretmen Metaforları, Sosyal Bilimler Enstitüsü Dergisi, 21, ss. 269-28.

ÇELIKKTEN, M., ŞANAL, M. ve YENİ, Y. (2005). Öğretmenlik Mesleği ve Özellikleri, Sosyal Bilimler Enstitü Dergisi, 19. ss. 207-237.

DÜNDAR, H. ve KARACA, E. T. (2013). Formasyon Öğrencilerinin Pedagojik Formasyon Programına İlişkin Sahip

242 | Celal Bayar Üniversitesi Sosyal Bilimler Dergisi - Cilt: 13, Sayı: 4, Aralık 2015 
Oldukları Metaforlar, Gazi Üniversitesi Endüstriyel Sanatlar Ĕgitim Fakültesi Dergisi, 30, ss. 19-34.

ERDEM, E. ve DEMIREL, Ö. (2002). Program Geliştirmede Yapılandırmacllık Yaklaşımı, Hacettepe Üniversitesi Eğitim Fakültesi Dergisi, 23, ss. 81-87.

FORCEVILLE, C. (2002). The Identification of Target and Source in Pictorial Metaphors, Journal of Pragmatics, 34(1), 1-14.

KARTAL, T. ve AFACAN, Ö. (2013). Pedagojik Formasyon Eğitimi Alan Öğretmen Adaylarının Öğretmenlik Mesleğine İlişkin Tutumlarının İncelenmesi, Mehmet Akif Ersoy Üniversitesi Eğitim Fakültesi Dergisi, 24, ss. 76-96.

LAKOFF, G. ve JOHNSON, M. (2005). Metaforlar: Hayat, Anlam ve Dil (Çeviren G.Y. Demir). İstanbul: Paradigma.

MILLES, M., B. and HUBERMAN, A., M. (1994). Qualitative Data Analysis: An Expended Sourcebook, 2. Edition, California: Sage Publications.

MILLER, S. (1987). Some comments on the utility of metaphors for educational theory and practice, Educational Theory, 37, ss. 219-227.

NALÇACI, A. ve BEKTAŞ, F. (2012). Öğretmen Adaylarının Okul Kavramına İlișkin Algıları, Ahi Evran Üniversitesi Kırșehir Eğitim Fakültesi Dergisi, 13(1), ss. 239-258.

ÖZDEN, Y. (1999). Eğitimde Dönüşüm Eğitimde Yeni Değerler, Ankara: PegemA Yayınları.

SABAN, A. (2004). Giriş Düzeyindeki Sınıf Öğretmeni Adaylarının "Öğretmen" Kavramına İlişkin İleri Sürdükleri Metaforlar. Türk Eğitim Bilimleri Dergisi. 2(2), ss. 131-155.

SABAN, A. ve KOCBEKER, B.N. (2006). Öğretmen Adaylarının Öğretmen Kavramına İlișkin Algılarının Metafor Analizi Yoluyla İncelenmesi, Kuram ve Uygulamada Eğitim Bilimleri (Educational Sciences: Theory \& Practice), 6(2), ss. 461-522.

SABAN, A. (2008). Okula İliş̧kin Metaforlar, Kuram ve Uygulamada Eğitim Yönetimi Dergisi, 55, ss. 459-496

SABAN, A. (2009). Öğretmen Adaylarının Öğrenci Kavramına İlişkin Sahip Olduğu Zihinsel İmgeler, Türk Eğitim Bilimleri Dergisi, 7(2), ss. 281-326.

ŞiŞMAN, M. (2007). Eğitim Bilimine Giriş, Ankara: Pegem A Yayıncilık.

TALIMM TERBIYE KURULU BAŞKANLIĞI (2014). Öğretmenlik Alanları, Atama ve Ders Okutma Esasları, Șubat, 2014.

YAPICI, M. ve YAPICI, Ş. (2013). Öğretmen Adaylarının Pedagojik Formasyona İlişkin Metaforları, Turkish Studies International Periodical For The Languages, Literature and History of Turkish or Turkic. 8(8), ss. 1421-1429. 
YILDIRIM, A. ve ŞİMŞEK, H. (2013). Sosyal Bilimlerde Nitel Araştırma Yöntemleri, Genişletilmiş 9. Baskl, Ankara: Seçkin Yayınevi. YÖK (1997). Eğitim Fakültesi Öğretmen Yetiștirme Lisans Programları. Y.Ö.K. Ankara.

YÖK (2010). Eğitim Fakültesi Öğretmen Yetiștirme Lisans Programları. Y.Ö.K. Ankara. 